Provided for non-commercial research and education use. Not for reproduction, distribution or commercial use.

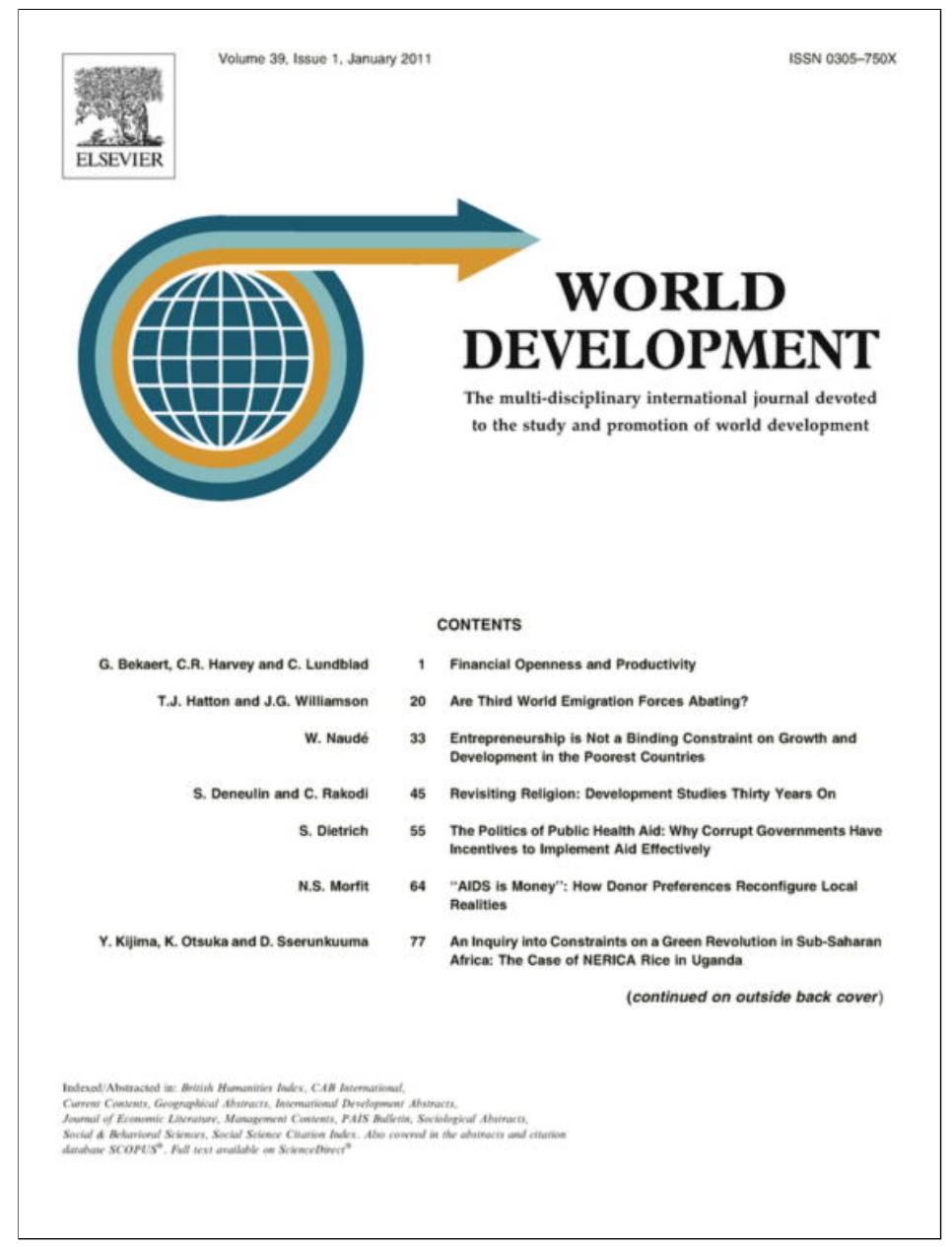

This article appeared in a journal published by Elsevier. The attached copy is furnished to the author for internal non-commercial research and education use, including for instruction at the authors institution and sharing with colleagues.

Other uses, including reproduction and distribution, or selling or licensing copies, or posting to personal, institutional or third party websites are prohibited.

In most cases authors are permitted to post their version of the article (e.g. in Word or Tex form) to their personal website or institutional repository. Authors requiring further information regarding Elsevier's archiving and manuscript policies are encouraged to visit:

http://www.elsevier.com/copyright 


\title{
Financial Openness and Productivity
}

\author{
GEERT BEKAERT \\ Columbia University, New York, NY, USA \\ National Bureau of Economic Research, Cambridge, MA, USA \\ CAMPBELL R. HAR VEY \\ Duke University, Durham, NC, USA \\ National Bureau of Economic Research, Cambridge, MA, USA
}

and

\author{
CHRISTIAN LUNDBLAD * \\ University of North Carolina, Chapel Hill, NC, USA
}

\begin{abstract}
Summary. - Financial openness is often associated with higher rates of economic growth. We show that the impact of openness on factor productivity growth is more important than the effect on capital growth. This explains why the growth effects of liberalization appear to be largely permanent, not temporary. We attribute these permanent liberalization effects to the role financial openness plays in stock market and banking sector development, and to changes in the quality of institutions. We find some indirect evidence of higher investment efficiency post-liberalization. We also document threshold effects: countries that are more financially developed or have higher quality of institutions experience larger productivity growth responses. Finally, we show that the growth boost from openness outweighs the detrimental loss in growth from global or regional banking crises.

(C) 2010 Elsevier Ltd. All rights reserved.
\end{abstract}

Key words - globalization, financial liberalization, economic growth, productivity, crisis

\section{INTRODUCTION}

Recent evidence strongly suggests a link between financial openness and economic growth. For example, Bekaert, Harvey, and Lundblad (2005) and Quinn and Toyoda (2008) document strong growth effects. However, Rodrik (1998) and Edison et al. (2002) find weak effects and a survey paper by Prasad, Rogoff, Wei, and Kose (2009) calls the collective evidence "mixed." This debate has largely been settled by two pieces of evidence. First, Quinn and Toyoda (2008) show that the "weak effects" are largely driven by measurement error in the financial openness variable used in these studies. Second, some new micro level studies, Gupta and Yuan (2009) at the industry level and Mitton (2006) at the firm level, confirm the positive growth effects of stock market liberalization and find them to be stronger than in Bekaert et al. (2005).

Nevertheless, this evidence generates an important issue. In the standard "neo-classical" model, a capital market liberalization lowers the cost of capital, thereby inducing additional investment and a temporary growth response. However, the decrease in the cost of capital appears rather modest (Bekaert \& Harvey, 2000; Henry, 2000), and the associated increase in investment is small relative to the large GDP growth increment (Henry, 2003). Of course, financial openness may also directly affect factor productivity, for example, by spurring financial development, promoting better corporate governance, or signaling higher quality governments (Rajan \& Zingales, 2003). Gourinchas and Jeanne (2006) argue that examining the productivity effects of international financial integration is far more important than considering its investment growth effects, as the latter have little chance of helping developing countries close the development gap. This is what we set out to do in this article.
Our first task is to decompose the per capita output growth effect into two channels: changes in factor productivity and investment growth. We find that factor productivity is the most important channel. Our work thereby fills a gap in the literature regarding the determinants of factor productivity growth. Much of the extant literature focuses on the beneficial effects of financial development, but part of that link may really be due to financial openness (see Bekaert, Harvey, Lundblad, \& Siegel (2007) for a related argument). ${ }^{1}$

Our results also complement the results of Borensztein, De Gregorio, and Lee (1998), which document that Foreign Direct Investment (FDI) improves factor productivity. We also provide a new analysis of which part of the growth response is temporary and which part is permanent. To shed more light on the sources of the permanent effect, we examine the effects of financial liberalization on future financial development and the quality of institutions. In related work, Ferreira and Matos (2008) provide evidence that foreign institutional investors promote improved corporate governance. We find that financial openness enhances the development and efficiency of the stock market, the quality of institutions, and macro-economic policies, but the results are not fully robust across specifications.

A simple mechanism for financial openness to affect productivity is that it improves domestic allocative efficiency. For example, in Obstfeld's (1994) model, openness allows coun-

\footnotetext{
*We appreciate the helpful comments of Xiaoyun Yu, the participants at the Emerging Markets Finance Conference at City University, London in June 2007, the 2009 McGill Conference on Global Asset Management, and the 2010 American Finance Association Meeting, two referees, and the editor. Final revision accepted: June 11, 2010.
} 
tries to more efficiently share risk and invest in the higher expected return, riskier projects. Again, the existing literature has focused on financial development, see for example, Fisman and Love (2004) and Wurgler (2000), but not on financial openness. Galindo, Schiantarelli, and Weiss (2007) show that domestic financial liberalization improves the efficiency of investment allocation. Our results suggest that investment is more sensitive to global growth opportunities in countries that are open to foreign investors. We are therefore able to generalize the results in, for instance, Chari and Henry (2008), who show that firm-specific investment in a sample of five countries is correlated with changes in growth opportunities after stock market liberalization.

We then go on to conduct an extensive interaction analysis examining on which local conditions lead to the largest investment growth and/or factor productivity growth responses. This evidence provides a new perspective on the existing work on the threshold effects in the relation between financial integration and growth (see Bekaert, Harvey, \& Lundblad, 2001, 2005; Edwards, 2001; Klein, 2003; Prasad et al., 2009). We find that both financial development and the quality of institutions produce positive interaction effects. This result is reminiscent of recent work on the effects of FDI on economic growth by Alfaro, Chanda, Kalemli-Ozcan, and Sayek (2004) and on FDI and factor productivity by Alfaro, Kalemli-Ozcan, and Sayek (2009), also showing positive interaction effects with the development of local financial markets.

Finally, one often hears the argument that globalization makes countries more susceptible to financial crises. ${ }^{2}$ We therefore directly examine the interaction between crises and financial liberalization. Ranciere, Tornell, and Westermann (2008) argue that a banking and currency crisis, such as the Asian crisis in 1997, may be the price to pay for the longerterm benefits of financial openness. We find that financial openness does not significantly increase the incidence of crises and that the output loss of a crisis is far outweighed by the output gain of financial liberalization.

Our results are of interest to the wider debate about the pros and cons of globalization. Stiglitz (2010) used the recent global crisis to reiterate that the existence of various market imperfections (information asymmetry, non-convex technologies, and incomplete markets) may make full global market integration undesirable. However, the conclusions from this post-Washington consensus (see Fine, 2002) are based on theoretical models, whereas we report robust empirical results that seem to at least challenge the policy implications of the new theories. Another important issue in the debate is the effect of financial openness on inequality. Wade (2004) argues that globalization may well have contributed to more inequality within and across countries, and has not served to close the income gap. Because increases in factor productivity have, at the very least, the potential to contribute to closing the income gap, we provide some simple empirical evidence regarding this issue in the conclusion. Financial openness has indeed reduced the income gap between rich and poor liberalizing countries; but, in fact, overall cross-sectional income dispersion has increased.

The paper is organized as follows: in Section 2, we introduce the data and the econometric methods used in the study. In the third section, we then present evidence on the link between financial openness and economic growth, decomposing the growth effect into investment growth and factor productivity. In the fourth section, we investigate threshold effects. In Section 5 we focus on the interaction between crises and financial openness. In the final section, we offer some concluding remarks.

\section{OUTPUT GROWTH AND FINANCIAL LIBERALIZATION}

\section{(a) Data}

Our data, spanning the 1980-2006 period and 96 countries, are drawn from a number of sources detailed in Table A.1. Some summary statistics are provided in Table A.2. While most variables do not require further explanation here, it is important to discuss how we measure capital stock and factor productivity growth. The growth in the capital stock is equal to aggregate real investment less depreciation in the capital stock divided by the previous year's capital stock. We build per capita physical capital stocks using the method described in King and Levine (1993). We derive an initial estimate of the capital stock for 1960, assuming each country is at its steady-state capital-output ratio at that time. Then, we use the aggregate real investment series and the perpetual inventory method with a depreciation rate of $7 \%$ to compute the capital stock in later years. Total factor productivity growth is constructed as in Beck, Levine, and Loayza (2000). Assuming a capital share of 0.3 for all countries, we calculate productivity growth as the difference between the GDP growth rate and 0.3 times the capital stock growth rate. Several articles have criticized the assumption of a country invariant capital share (see, e.g., Gollin, 2002). We therefore consider an alternative computation which uses the country-specific capital shares for the manufacturing sector reported in Ortega and Rodrguez (2006), but re-scaled to average 0.35 across countries.

We employ several measures of financial openness. First, our capital market openness variable uses data from the IMF's Annual Report on Exchange Arrangement and Exchange Restrictions. There are six categories of restrictions. If any restriction is in place, the standard indicator takes a value of zero suggesting that the capital account is closed. Because of its coarseness, this variable has been discredited in the literature, see for example, Eichengreen (2001). We instead employ Quinn's (1997) measure of capital account openness (see also Quinn \& Toyoda, 2008). While relying on the same IMF data, Quinn scores each of these restrictions, separately for capital payments and receipts, on a scale of $0-2$ ( 0.5 increments), and then adds the two. Quinn's system investigates the need for official approval, the likelihood it is granted, and the presence of taxes. It therefore measures the degree to which the capital account is open. The measure is available for 78 of our 96 countries.

Second, to measure equity market openness, we use the official financial openness measure based on Bekaert and Harvey's (2005) Chronology of Important Economic, Financial and Political Events in Emerging Markets. The official liberalization measure is an indicator variable that takes the value of one once a country allows foreigners to transact in the local equity market. The official equity market liberalization variable is available for all 96 countries.

Last, we consider an additional measure of equity market openness, proposed by Bekaert (1995) and Edison and Warnock (2003), to explore the robustness of our measured effects to the dating of financial liberalization. The equity market openness measure is a continuous variable that reflects the ratio of market capitalization available to foreign investors divided by the total market capitalization of all domestically listed firms. For this measure, a value of zero means that the market is segmented to foreigners and a value of one means that the entire market capitalization is available to foreign investors. 


\section{(b) Econometric framework}

Define $y_{i, t}$ as the log growth rate in per capita real GDP, capital stock, or total factor productivity for country $i$. Our dependent variable is growth over 5 years:

$y_{i, t+5,5}=\frac{1}{5} \sum_{j=1}^{5} y_{i, t+j}, \quad i=1, \ldots, N$,

where $N$ is the number of countries in our sample. Our main panel regression is specified as:

$y_{i, t+5, t}=\beta Q_{i, \text { start }}+\gamma^{\prime} \mathbf{X}_{i, t}+\alpha \operatorname{Lib}_{i, t}+\epsilon_{i, t+5,5}$,

where $Q_{i, \text { start }}$ represents the logarithm of initial per capita real GDP, reset at 5-year intervals $(1980,1985$, etc.). In the standard neo-classical framework, the $X_{i, t}$ variables control for steady-state per capita GDP levels, which may differ across countries. The $Q_{i, \text { start }}$ variable functions as initial GDP and $\beta$ is the conditional convergence coefficient which is expected to be negative. When steady-state GDP is raised (e.g., through policy reforms) above initial GDP, the country will converge toward the higher per capita GDP level. To maximize the time-series content in our regression, we use overlapping data. We use a pooled OLS estimate but the reported standard errors reflect groupwise heteroskedasticity, SUR effects, and a Newey and West (1987) adjustment with five lags for serial correlation (accounting for the overlapping nature of the data).

There are two neo-classical channels through which liberalization can affect growth. First, the flow of capital from capital-rich to capital-poor countries lowers the real interest rate in liberalizing countries, increases investment, and spurs growth. Gourinchas and Jeanne (2006) suggest that many developing countries are not particularly capital scarce and that this effect only leads to faster convergence to a too low steady-state per capita GDP. Second, the international finance literature suggests that open equity markets reduce the equity risk premium because of improved risk sharing. This intuition goes back to Errunza and Losq (1985) and was tested in Bekaert and Harvey (2000) and Henry (2000). As the cost of capital decreases, more investment projects should have positive net present value. This should spur investment that is financed either locally or by foreign capital. The increased investment leads to increased output growth. From the perspective of the neo-classical model, the improved risk sharing and foreign presence in local capital markets are bound to raise the steady-state level of GDP. If this is the case, accounting for financial openness should imply that the regression framework should control for the true steady-state GDP and the convergence coefficient should increase, a hypothesis we test below. Nevertheless, the growth spurt remains temporary within the neoclassical framework.

\section{DECOMPOSING THE GROWTH EFFECT OF FINANCIAL LIBERALIZATION}

\section{(a) The decomposition}

Table 1 presents the impact of both capital account openness and official equity market liberalization on real per capita GDP, capital stock, and total factor productivity growth. Each regression includes year indicator variables (though these coefficients are not reported). We include, in addition to initial per capita GDP, four standard control variables: a human capital measure (secondary school enrollment), the logarithm of life expectancy (health care), trade openness (ex- ports plus imports divided by GDP), and private credit to GDP (financial development). Note that our factor productivity growth measure does not account for human capital accumulation. There is a lively debate on how human capital should be taken into account in growth accounting exercises (see Bils \& Klenow, 2000; Bosworth \& Collins, 2003), which is beyond the scope of this article. However, we always include human capital as an independent variable in all of our specifications.

We begin with an exploration of the GDP growth effects in the left-most column of each group in Table 1. While we concentrate our discussion on the coefficients associated with the financial openness variables, the signs on the other coefficients are consistent with the previous literature (see Barro, 1997a, 1997b; Barro \& Sala-i-Martin, 1995). The coefficients on initial GDP are negative and highly significant, which is precisely what one would expect from a conditional convergence interpretation. The coefficients for all the other variables also have the expected sign and are also statistically significant. Turning to financial openness, the coefficients on capital market and equity market openness are statistically significant (both more than four standard errors from zero). The results suggest openness boosts per capita real GDP growth by an economically meaningful $0.98-1.5 \%$ per year.

The growth result may be surprising to some given the fact that some well-publicized articles, such as Rodrik (1998), have found no growth effect associated with general capital account openness. However, as both Bekaert et al. (2005) and Quinn and Toyoda (2008) discuss, Rodrik's result reflects the use of the simple $0 / 1$ IMF indicator, which is too coarse to be a meaningful gauge of the degree of capital market openness. For our particular sample, using this indicator leads to a coefficient of $0.15 \%$ with a standard error of 0.0014 (results are available upon request). Table 1 helps resolve the mixed evidence regarding the growth effects of financial openness reported by survey articles. These surveys give undue weight to empirical studies which use a problematic measure of financial openness. ${ }^{3}$

Table 1 also shows the capital stock and factor productivity growth effects in the two other sets of columns. We find that capital stock growth is significantly associated with both capital account openness and equity market liberalization, even in the presence of a banking development variable (private credit divided by GDP). In both sets of regressions, banking development itself is positively and significantly associated with higher capital stock growth. These results are inconsistent with the results in Beck et al. (2000), who fail to find a direct effect of financial development on capital stock growth.

Our results also resolve the critique provided by Henry (2003), who appeals to the neo-classical growth model to argue that the GDP growth effects of financial openness are "too big." To review the argument, consider the Solow (1956) growth model:

$\Delta(Y / L)=\Delta A+\alpha \Delta(K / L)$,

where $\Delta(Y / L)$ is the change in the output per worker, $\Delta(K / L)$ is the growth in the capital stock per worker, $\Delta A$ is the change in total factor productivity and $\alpha$ is the growth elasticity to capital inputs, reflecting the capital share in output. Using a standard estimate for $\alpha$ equal to 0.3 , the model implies that a capital stock growth effect of $1.2-1.7 \%$ implies a "neo-classical" growth effect of 35-50 basis points across the two regressions.

Henry (2003) concludes that the growth effects of equity market liberalization reported in Bekaert et al. (2005) are too large and must be due to measurement error in the liberalization effect. He suggests that the effect is likely due 
WORLD DEVELOPMENT

Table 1. Financial openness and growth components

\begin{tabular}{|c|c|c|c|c|c|c|c|c|}
\hline \multirow[t]{2}{*}{ Number of countries } & \multicolumn{4}{|c|}{ Capital account openness } & \multicolumn{4}{|c|}{ Official equity market liberalization } \\
\hline & $\begin{array}{l}\text { GDP } \\
\text { growth } \\
78\end{array}$ & $\begin{array}{l}\text { Capital stock } \\
\text { growth } \\
78\end{array}$ & $\begin{array}{l}\text { Total factor } \\
\text { productivity } \\
78\end{array}$ & $\begin{array}{c}\text { Total factor } \\
\text { productivity (alt.) } \\
67\end{array}$ & $\begin{array}{l}\text { GDP } \\
\text { growth } \\
96\end{array}$ & $\begin{array}{l}\text { Capital stock } \\
\text { growth } \\
96\end{array}$ & $\begin{array}{l}\text { Total factor } \\
\text { productivity } \\
96\end{array}$ & $\begin{array}{c}\text { Total factor } \\
\text { productivity (alt.) } \\
77\end{array}$ \\
\hline Constant & $\begin{array}{c}-0.2109 \\
(0.0458)\end{array}$ & $\begin{array}{c}-0.1634 \\
(0.0268)\end{array}$ & $\begin{array}{c}-0.1619 \\
(0.0397)\end{array}$ & $\begin{array}{c}-0.1336 \\
(0.0315)\end{array}$ & $\begin{array}{c}-0.2580 \\
(0.0415)\end{array}$ & $\begin{array}{c}-0.2519 \\
(0.0267)\end{array}$ & $\begin{array}{c}-0.1823 \\
(0.0351)\end{array}$ & $\begin{array}{c}-0.1537 \\
(0.0291)\end{array}$ \\
\hline Initial GDP & $\begin{array}{r}-0.0136 \\
(0.0009)\end{array}$ & $\begin{array}{r}-0.0149 \\
(0.0012)\end{array}$ & $\begin{array}{c}-0.0091 \\
(0.0007)\end{array}$ & $\begin{array}{c}-0.0063 \\
(0.0006)\end{array}$ & $\begin{array}{c}-0.0111 \\
(0.0009)\end{array}$ & $\begin{array}{c}-0.0132 \\
(0.0011)\end{array}$ & $\begin{array}{c}-0.0071 \\
(0.0007)\end{array}$ & $\begin{array}{c}-0.0057 \\
(0.0006)\end{array}$ \\
\hline Secondary school & $\begin{array}{c}0.0315 \\
(0.0043)\end{array}$ & $\begin{array}{c}0.0185 \\
(0.0022)\end{array}$ & $\begin{array}{c}0.0260 \\
(0.0042)\end{array}$ & $\begin{array}{c}0.0220 \\
(0.0036)\end{array}$ & $\begin{array}{c}0.0170 \\
(0.0032)\end{array}$ & $\begin{array}{c}0.0055 \\
(0.0021)\end{array}$ & $\begin{array}{c}0.0154 \\
(0.0031)\end{array}$ & $\begin{array}{c}0.0158 \\
(0.0030)\end{array}$ \\
\hline $\log (\operatorname{life})$ & $\begin{array}{c}0.0700 \\
(0.0122)\end{array}$ & $\begin{array}{c}0.0663 \\
(0.0081)\end{array}$ & $\begin{array}{c}0.0501 \\
(0.0103)\end{array}$ & $\begin{array}{c}0.0411 \\
(0.0082)\end{array}$ & $\begin{array}{c}0.0796 \\
(0.0115)\end{array}$ & $\begin{array}{c}0.0875 \\
(0.0081)\end{array}$ & $\begin{array}{c}0.0533 \\
(0.0095)\end{array}$ & $\begin{array}{c}0.0461 \\
(0.0079)\end{array}$ \\
\hline Trade/GDP & $\begin{array}{c}0.0073 \\
(0.0009)\end{array}$ & $\begin{array}{c}0.0075 \\
(0.0012)\end{array}$ & $\begin{array}{c}0.0051 \\
(0.0007)\end{array}$ & $\begin{array}{c}0.0030 \\
(0.0008)\end{array}$ & $\begin{array}{c}0.0071 \\
(0.0011)\end{array}$ & $\begin{array}{c}0.0083 \\
(0.0012)\end{array}$ & $\begin{array}{c}0.0046 \\
(0.0010)\end{array}$ & $\begin{array}{c}0.0040 \\
(0.0009)\end{array}$ \\
\hline Private credit/GDP & $\begin{array}{c}0.0081 \\
(0.0024)\end{array}$ & $\begin{array}{c}0.0122 \\
(0.0029)\end{array}$ & $\begin{array}{c}0.0045 \\
(0.0019)\end{array}$ & $\begin{array}{c}0.0037 \\
(0.0019)\end{array}$ & $\begin{array}{c}0.0045 \\
(0.0019)\end{array}$ & $\begin{array}{c}0.0070 \\
(0.0027)\end{array}$ & $\begin{array}{c}0.0024 \\
(0.0015)\end{array}$ & $\begin{array}{c}0.0018 \\
(0.0016)\end{array}$ \\
\hline $\begin{array}{l}\text { Financial openness } \\
\text { Contribution to growth }\end{array}$ & $\begin{array}{c}0.0150 \\
(0.0033)\end{array}$ & $\begin{array}{l}0.0167 \\
(0.0028) \\
33.5 \%\end{array}$ & $\begin{array}{l}0.0099 \\
(0.0028) \\
66.4 \%\end{array}$ & $\begin{array}{c}0.0067 \\
(0.0030)\end{array}$ & $\begin{array}{c}0.0098 \\
(0.0026)\end{array}$ & $\begin{array}{l}0.0118 \\
(0.0022) \\
36.2 \%\end{array}$ & $\begin{array}{l}0.0063 \\
(0.0021) \\
63.8 \%\end{array}$ & $\begin{array}{c}0.0060 \\
(0.0018)\end{array}$ \\
\hline $\begin{array}{l}\text { Financial openness } \\
\text { (3-year non-overlapping) } \\
\text { Contribution to growth }\end{array}$ & $\begin{array}{c}0.0149 \\
(0.0057)\end{array}$ & $\begin{array}{l}0.0147 \\
(0.0035) \\
29.7 \%\end{array}$ & $\begin{array}{l}0.0104 \\
(0.0049) \\
69.9 \%\end{array}$ & $\begin{array}{c}0.0064 \\
(0.0046)\end{array}$ & $\begin{array}{c}0.0117 \\
(0.0023)\end{array}$ & $\begin{array}{l}0.0117 \\
(0.0027) \\
30.0 \%\end{array}$ & $\begin{array}{l}0.0082 \\
(0.0023) \\
70.1 \%\end{array}$ & $\begin{array}{c}0.0079 \\
(0.0022)\end{array}$ \\
\hline
\end{tabular}

The dependent variables are the overlapping 5-year average growth rate of real per capita gross domestic product (GDP), the growth rate of the real capital stock, and total factor productivity growth. In addition to a set of standard control variables and year effects, we report the coefficient on financial openness defined as (1) Quinn's capital account openness indicator that takes a value between 0 and 1 depending upon the intensity of the reported capital account openness and (2) the official liberalization indicator that takes a value of one when the equity market is liberalized, and zero otherwise. Given data limitations, the capital account openness regressions include 78 countries and the official equity market liberalization regressions include 96 countries. The regressions cover 1980-2006. We report coefficient estimates from pooled OLS regressions. All standard errors (in parentheses) provide a correction for cross-sectional heteroskedasticity and account for the overlapping nature of the data. The final entries provide alternative estimates based on 3-year nonoverlapping observations. Finally, we include a percentage decomposition of the financial openness effect on GDP growth into capital stock accumulation and total factor productivity (it does not sum to $100 \%$ due to rounding). The capital stock component is calculated as 0.3 , the assumed capital share, multiplied by the reported financial openness effect for capital stock growth. In the (alt.) column, the capital share is country-specific. The total factor productivity component is the reported financial openness effect in the factor productivity regression.

to equity market liberalization being correlated with other reforms, such as trade liberalization. However, such a conclusion seems premature. First, Table 1 controls for trade openness in the growth regression. Second, when we consider an alternative regression in which we replace trade openness with the trade liberalization dates reported in Wacziarg and Welch (2008), we find similar results. ${ }^{4}$ Third, and most importantly, it is reasonable to expect that financial openness raises factor productivity, as would be reflected in $\Delta A$. Given that the closing of the development gap requires significant improvements in factor productivity (see Gourinchas \& Jeanne, 2006), it is important to test the link between factor productivity and liberalization directly.

The remaining columns in Table 1 confirm that the effects of capital account openness and equity market liberalization on factor productivity growth are indeed both large and statistically significant. Decomposing the measured GDP growth effect into the capital stock and total factor productivity growth effects, nearly two-thirds of the overall GDP growth effect is attributable to total factor productivity for both measures of financial openness. We also report results for two alternative specifications. In the fourth column in each panel, factor productivity growth is computed using country-specific capital shares adapted from Ortega and Rodrguez (2006), which reduces the number of countries in the sample somewhat. The effect of capital account openness on factor productivity growth decreases to 67 basis points, and is no longer statistically significant; however, in the case of equity market liberalization, the productivity effect is largely the same as in the case with a constant capital share. The second additional specification, reported in the last few rows of Table 1, uses 3 year nonoverlapping growth data, decomposed into capital stock growth and factor productivity growth. All the conclusions remain robust, with factor productivity growth accounting for a slightly larger proportion of the openness effect than in the main specification. In all, our results suggest that factor productivity cannot be ignored when examining financial openness and growth.

In Table 2, we explore the robustness of the financial openness effects on GDP, capital stock, and total factor productivity growth. In the first two regressions, we examine the implications of introducing country-fixed effects (the fixed effects themselves are not reported to conserve space). Here, we also include a contemporaneous measure of world GDP growth to control for temporal effects, but do not include other control variables. ${ }^{5}$ In both cases, the financial openness effects remain large and statistically significant. Again, the bulk of the effect is due to factor productivity gains, and indeed the decomposition reveals a factor productivity channel that is even stronger when country-fixed effects are included.

In the next two regressions reported in Table 2, we report the results for our alternative measure of equity market 
Table 2. Financial openness and growth components: robustness

\begin{tabular}{|c|c|c|c|}
\hline & GDP growth & Capital stock growth & Total factor productivity \\
\hline Capital account openness & 0.0227 & 0.0123 & 0.0190 \\
\hline (Fixed effects) & $(0.0039)$ & $(0.0024)$ & $(0.0040)$ \\
\hline Contribution to growth & & $16.3 \%$ & $83.7 \%$ \\
\hline Official equity market liberalization & 0.0131 & 0.0033 & 0.0122 \\
\hline (Fixed effects) & $(0.0022)$ & $(0.0011)$ & $(0.0021)$ \\
\hline Contribution to growth & & $7.5 \%$ & $92.5 \%$ \\
\hline Equity market openness & 0.0136 & -0.0006 & 0.0138 \\
\hline (Fixed effects) & $(0.0030)$ & $(0.0017)$ & $(0.0029)$ \\
\hline Contribution to growth & & $-1.3 \%$ & $101.3 \%$ \\
\hline Equity market openness & 0.0085 & 0.0084 & 0.0060 \\
\hline (Standard controls) & $(0.0022)$ & $(0.0019)$ & $(0.0020)$ \\
\hline Contribution to growth & & $29.5 \%$ & $70.5 \%$ \\
\hline \multirow[t]{2}{*}{ Capital account openness } & 0.0134 & 0.0129 & 0.0095 \\
\hline & $(0.0033)$ & $(0.0025)$ & $(0.0030)$ \\
\hline \multirow[t]{2}{*}{ Probability of capital account openness } & 0.0196 & 0.0237 & 0.0125 \\
\hline & $(0.0030)$ & $(0.0022)$ & $(0.0026)$ \\
\hline \multirow[t]{2}{*}{ Equity market openness } & 0.0071 & 0.0094 & 0.0043 \\
\hline & $(0.0023)$ & $(0.0021)$ & $(0.0020)$ \\
\hline \multirow[t]{2}{*}{ Probability of equity market openness } & 0.0243 & 0.0218 & 0.0178 \\
\hline & $(0.0026)$ & $(0.0024)$ & $(0.0025)$ \\
\hline
\end{tabular}

The dependent variables are the overlapping 5-year average growth rate of real per capita gross domestic product (GDP), the growth rate of the real capital stock, and total factor productivity growth. We report the coefficient on financial openness defined as (1) Quinn's capital account openness indicator that takes a value between zero and one depending upon the intensity of the reported capital account openness; (2) the official liberalization indicator that takes a value of one when the equity market is liberalized, and zero otherwise; and (3) an alternative measure of the degree of equity market openness (investability). In this table, we consider robustness of the effects reported in Table 1 to specifications that instead include country-fixed effects and contemporaneous world GDP growth. To explore robustness to alternative measures of financial openness, we also consider the identical specifications employed in Table 1 for equity market openness. Given data limitations, the capital account openness regressions include 78 countries and the official equity market liberalization and equity market openness regressions include 96 countries. The regressions cover 1980-2006. We report coefficient estimates from pooled OLS regressions. All standard errors (in parentheses) provide a correction for cross-sectional heteroskedasticity and account for the overlapping nature of the data. We include a percentage decomposition of the financial openness effect on GDP growth into capital stock accumulation and total factor productivity. Finally, the last two sets of regressions include the predicted probability of capital account ( 71 countries due to the variables needed to estimate the probit) or equity openness ( 81 countries) based on panel probit regressions of the relevant financial openness variables onto the contemporaneous trade/GDP, private credit/GDP, log country credit ratings, and the quality of institutions variables (see Table 3). Here, we also report, for comparison, the coefficient and standard error on this predicted probability of financial liberalization. The capital stock component is calculated as 0.3 , the assumed capital share, multiplied by the reported financial openness effect for capital stock growth. The total factor productivity component is the reported financial openness effect in the factor productivity regression.

openness discussed above. The first regression repeats the country-fixed effect specification and the second regression repeats the specification including the standard control variable set employed in Table 1 . The results, quite similar to but somewhat weaker than the official equity market liberalization effects, buttress the argument that there exists an important effect for equity market liberalization on growth, particularly for total factor productivity. To conserve space, we do not employ this alternative financial openness variable further.

Finally, our results are for relatively large samples of countries ( 96 or 78 , depending upon the openness measure). In unreported results, we also redo our analysis for a smaller subset of about 50 countries for which we have better quality data. To provide a sense of the results, the GDP growth effects in the smaller sample for capital account and equity market openness are $2.00 \%$ and $0.98 \%$, respectively, with a very similar one-third/ two-third split between capital stock and TFP growth.

\section{(b) Endogeneity concerns}

One standard critique of a regression framework such as Eqn. (2) is the possibility of reverse causality: countries liber- alize exactly because they are experiencing favorable growth opportunities. While hard to rule out completely, this criticism seems unfounded. It is implausible that governments would correctly identify such favorable growth opportunities and perfectly time the liberalization accordingly. Bekaert et al. (2005) control for growth opportunities by adding an exogenous growth opportunity measure to the growth regressions. The measure employs global valuation ratios to capture the growth opportunities of the industry mix in which the liberalizing country specializes. Bekaert et al. (2007) show that this measure significantly predicts real economic growth in a panel of emerging markets, and is a better measure of growth opportunities than local valuation ratios. Our results in Tables 1 and 2 are robust to the addition of this growth opportunities measure. ${ }^{6}$

Nevertheless, it is still conceivable that governments would push for liberalization because they recognize the growing need for capital in their economies or that it is exactly those countries with the right mix of institutions that liberalize. Research on the causes of financial liberalization (see, e.g., Quinn \& Inclan (1997)) mostly finds that they are entirely politically driven. ${ }^{7}$ It is still possible that the liberalization variable captures effects of other reforms happening simultaneously. 
Table 3. Predicting financial openness

\begin{tabular}{lcc}
\hline & $\begin{array}{c}\text { Capital account } \\
\text { openness }\end{array}$ & $\begin{array}{c}\text { Official equity } \\
\text { market liberalization }\end{array}$ \\
\hline Constant & -8.6992 & -8.2423 \\
& $(0.9313)$ & $(0.7715)$ \\
Trade/GDP & 3.5194 & 3.2533 \\
Private credit/GDP & $(0.4640)$ & $(0.4363)$ \\
& -0.2791 & 2.6917 \\
Log(country credit rating) & $(0.4414)$ & $(0.3352)$ \\
ICRG quality of institutions & 1.4669 & 0.8830 \\
& $(0.2185)$ & $(0.1850)$ \\
& 4.2673 & 2.3495 \\
& $(0.6310)$ & $(0.4521)$ \\
\hline
\end{tabular}

The dependent variable in the panel probit estimation is a $0 / 1$ indicator measuring financial openness. To identify the capital account liberalization dates, we define a liberalization event as an upward increment of 0.2 or larger in Quinn's openness measure that results in the measure then exceeding 0.5 . For the official liberalization indicator, the date of liberalization is directly employed. Given data limitations, the capital account openness regressions include 71 countries and the official equity market liberalization regressions include 81 countries. Standard errors are provided in parentheses.

To examine this further, Table 3 reports results of a panel probit on liberalization. The official equity market liberalization is a $0 / 1$ variable already, and we also construct a $0 / 1$ capital account liberalization variable (constructed from Quinn's measure), which we describe in the next section. As independent variables, we use contemporaneous measures of private credit to GDP, trade to GDP, the ICRG's political risk index, and the log of the country credit rating. These variables may capture banking, trade, macro-economic, or other reforms. In both versions of the probit specification, we find positive significant coefficients for all four variables, suggesting that the probability of financial openness is indeed directly related to other reforms. We then use the estimated probit to compute a "probability of liberalization" for each country at each point in time, and use that as an additional control variable. ${ }^{8}$

We report the coefficients on both the financial openness indicator and the financial openness probability in the last two rows of Table 2 . The effect of the financial openness indicator is now, at least partially, cleansed of certain reverse causality biases. The financial openness effects remain statistically significant even in the presence of the probability of openness variable.

\section{(c) Exploring the neo-classical channels}

In the neo-classical model, financial integration does not generate a permanent growth effect. With data extending beyond 2000 and many liberalizations occurring in the late 1980s and early 1990s, we are now able to investigate this implication of the model directly. Table 4 presents results where we break up the financial liberalization effects into

Table 4. Financial openness and growth components: temporary versus permanent effects

\begin{tabular}{|c|c|c|c|c|}
\hline & GDP growth & Capital stock growth & Total factor productivity & GDP growth (liberalizing countries only) \\
\hline \multicolumn{5}{|c|}{ Capital account openness (standard controls) } \\
\hline Temporary effect & $\begin{array}{c}0.0045 \\
(0.0034)\end{array}$ & $\begin{array}{c}-0.0025 \\
(0.0030)\end{array}$ & $\begin{array}{c}0.0052 \\
(0.0028)\end{array}$ & $\begin{array}{c}0.0042 \\
(0.0057)\end{array}$ \\
\hline Permanent effect & $\begin{array}{l}0.0125 \\
(0.0022)\end{array}$ & $\begin{array}{r}0.0107 \\
(0.0018)\end{array}$ & $\begin{array}{c}0.0092 \\
(0.0018)\end{array}$ & $\begin{array}{c}0.0164 \\
(0.0059)\end{array}$ \\
\hline \multicolumn{5}{|c|}{ Capital account openness (fixed effects) } \\
\hline Temporary effect & $\begin{array}{l}0.0160 \\
(0.0023)\end{array}$ & $\begin{array}{r}0.0040 \\
(0.0015)\end{array}$ & $\begin{array}{c}0.0149 \\
(0.0024)\end{array}$ & $\begin{array}{c}0.0160 \\
(0.0048)\end{array}$ \\
\hline Permanent effect & $\begin{array}{l}0.0167 \\
(0.0026)\end{array}$ & $\begin{array}{r}0.0065 \\
(0.0018)\end{array}$ & $\begin{array}{c}0.0147 \\
(0.0028)\end{array}$ & $\begin{array}{c}0.0194 \\
(0.0059)\end{array}$ \\
\hline \multicolumn{5}{|c|}{ Official equity market liberalization (standard controls) } \\
\hline Temporary effect & $\begin{array}{l}0.0139 \\
(0.0022)\end{array}$ & $\begin{array}{r}0.0125 \\
(0.0021)\end{array}$ & $\begin{array}{c}0.0101 \\
(0.0017)\end{array}$ & $\begin{array}{c}0.0154 \\
(0.0039)\end{array}$ \\
\hline Permanent effect & $\begin{array}{l}0.0079 \\
(0.0024)\end{array}$ & $\begin{array}{r}0.0100 \\
(0.0020)\end{array}$ & $\begin{array}{c}0.0049 \\
(0.0021)\end{array}$ & $\begin{array}{c}0.0093 \\
(0.0055)\end{array}$ \\
\hline \multicolumn{5}{|c|}{ Official equity market liberalization (fixed effects) } \\
\hline Temporary effect & $\begin{array}{l}0.0158 \\
(0.0024)\end{array}$ & $\begin{array}{r}0.0059 \\
(0.0012)\end{array}$ & $\begin{array}{c}0.0140 \\
(0.0022)\end{array}$ & $\begin{array}{c}0.0152 \\
(0.0030)\end{array}$ \\
\hline Permanent effect & $\begin{array}{l}0.0148 \\
(0.0025)\end{array}$ & $\begin{array}{r}0.0019 \\
(0.0014)\end{array}$ & $\begin{array}{c}0.0142 \\
(0.0024)\end{array}$ & $\begin{array}{c}0.0134 \\
(0.0040)\end{array}$ \\
\hline
\end{tabular}

The dependent variables are the overlapping 5-year average growth rate of real per capita gross domestic product (GDP), the growth rate of the real capital stock, and total factor productivity growth. We report temporary and permanent effects from financial openness defined as the first 5 years after a liberalization event and the 6+ years beyond, respectively. Fully open countries are associated with the permanent effect, and closed countries are associated with neither. For capital account openness, we define a liberalization event as an upward increment of 0.2 or larger in Quinn's openness measure that results in the measure exceeding 0.5 . For the official liberalization indicator, the date of liberalization is directly employed. Given data limitations, the capital account openness regressions include 78 countries and the official equity market liberalization regressions include 96 countries. The final column provides alternative estimates for a sample that includes only those countries that liberalize in our sample. The regressions cover 1980-2006. We report the effects with (1) standard controls and time effects and (2) country-fixed effects and the contemporaneous world GDP growth rate. The last column considers the GDP growth effects for a sample restricted to liberalizing countries only (38 or 41 countries, respectively, for capital account and equity market liberalization). We report coefficient estimates from pooled OLS regressions. All standard errors (in parentheses) provide a correction for crosssectional heteroskedasticity and account for the overlapping nature of the data. 
two pieces: years 1-5, and years 6 and beyond. We explore these effects for both capital account and equity market liberalization. While the equity market liberalization date is known, the date of capital account liberalization is not. To identify the capital account liberalization date, we define a liberalization event as an upward increment of 0.2 or larger in Quinn's openness measure that results in the measure then exceeding 0.5 . For both sets of liberalization dates, fully open countries are associated with the permanent effect as they are indeed open, by definition, and have been so for some time. Closed countries are associated with neither a temporary nor a permanent effect, and receive a zero.

We report the temporary and permanent effects with both standard controls as employed in Table 1 and an alternative specification that includes country-fixed effects as in Table 2. Across all four specifications, the GDP growth results suggest that the financial liberalization effect, either the general capital account or the specific equity market, is not a purely temporary phenomenon. The coefficients on the variable representing years 6 and beyond, denoted the permanent effect, is always positive and significantly different from zero. The effects for capital stock growth are not uniformly significant across every specification. Somewhat surprisingly, the temporary capital stock growth effect is not uniformly stronger than the permanent effect, but it is for equity market liberalization where identifying permanent and temporary liberalization effects is easier. The permanent factor productivity growth effect is statistically significant in every case, ranging between 49 and 147 basis points per annum.

We also consider an alternative specification that includes only liberalizing countries (see the last column of Table 4), that is, countries that undergo the liberalization described above in our sample. The magnitudes of the temporary effects are similar, and the permanent effects are even larger in three of the four cases, compared to the full sample results. Perhaps not surprising, the standard errors increase, but the permanent effect remains highly significant, except in the case of official equity market liberalization with standard controls, where the $t$-statistic drops to 1.72 .

Another implication of the neo-classical model is that controlling for liberalization should entail a larger conditional convergence coefficient (in absolute terms). That is, once we control for the effect of financial openness on steady-state per capita GDP, we should observe stronger conditional convergence (the coefficient on the initial GDP level). This is indeed what we find. To provide a sense of the evidence, the convergence coefficient is -0.0107 for a specification without capital account liberalization that is otherwise identical to one we report in Table 1 . The conditional convergence coefficient reported in Table 1 is -0.0136 , substantially larger in absolute magnitude. The difference is significant at the 5\% level, suggesting the inclusion of the capital account openness measure is associated with stronger conditional convergence everything else equal. We observe similar effects for our equity market openness variables.

\section{(d) Sources of improved factor productivity}

In this section, we examine a number of different channels through which financial openness may affect factor productivity. We focus primarily on two generally accepted sources of long-term growth: financial development (Beck et al., 2000) and institutional quality (Acemoglu, Johnson, \& Robinson, 2001). We also investigate some proxies for the quality of macro-economic policies, but these may be correlated with institutional quality. Our indicators are undoubtedly corre- lated with what Hall and Jones (1999) term "social infrastructure" and identify as the main driver of variation in output per worker across countries.

First, the presence of foreign investors may directly spur financial development. For instance, foreign investor access can improve equity market liquidity and price efficiency. To explore this, we investigate the financial openness effects on two standard measures of stock market liquidity/development, namely the liquidity measure based on zero daily returns used in Lesmond (2005) and Bekaert et al. (2007) and equity market turnover. For general stock market development, we also consider the ratio of market capitalization to GDP. Finally, we use the measure of price in efficiency proposed in Morck, Yeung, and $\mathrm{Yu}$ (2000). Financial openness may also effect banking sector development. For example, openness may go hand in hand with increased foreign ownership of domestic banks, which can entail increased access to international financial markets, technological spillovers, increased competition, and improved regulatory oversight. Our measure for banking development is the standard ratio of private credit to GDP.

Second, we investigate the effects of financial openness on institutional quality. Foreign investors may directly demand better corporate governance, and have associated disciplining effect on governments. The cost of bad government actions may be more severe when foreign investors are likely to leave following policy actions that hamper investments and growth. Conversely, capital controls can provide a screen behind which the government can channel resources to "favored" firms and hence, distort resource allocation. Johnson and Mitton (2003) show how the imposition of capital controls in 1998 increased cronyism in Malaysia.

To investigate whether financial openness improves the quality of institutions, we rely primarily on data from the International Country Risk Guide (see Table A.1), a country risk-rating agency. We investigate three measures. First, "investment profile" measures the general attractiveness of a country for foreign investment and FDI by scoring contract viability, payment delays, and ability to repatriate capital. It is one sub-category from the ICRG's composite political risk rating. Second, we also use the ICRG's "law and order" rating, which is perhaps most directly related to corporate governance. We also merge three components of the political risk rating, "law and order," "bureaucratic quality," and "corruption" into one "quality of institutions" measure. Finally, we consider the economic rating from ICRG, as a measure of the quality of macro-economic policies. The measure is outcome-based, combining statistics on economic levels and growth, inflation, and fiscal and trade balances. To check robustness, we also use Institutional Investor's country credit ratings. For all these measures, substantial panel data are available.

It is important to stress that our measures of institutional quality do indeed exhibit time-variation unlike many measures used in the literature. Figure 1 shows the time evolution of the investment profile measure for five countries selected as the 10th, 25th, 50th, 75th, and 90th percentile countries in the cross-sectional distribution at the outset of our sample. Not only does this measure indeed fluctuate, but also the example shows one country in which conditions improve (Sweden) and another where conditions rapidly deteriorate (Zimbabwe).

The regressions we run are predictive; that is, for the independent variable (a development indicator), we use 5-year averages between $t$ and $t+5$. The potential determinants, including liberalization, are measured at time $t$. These regressions face a number of challenges. First, the independent 


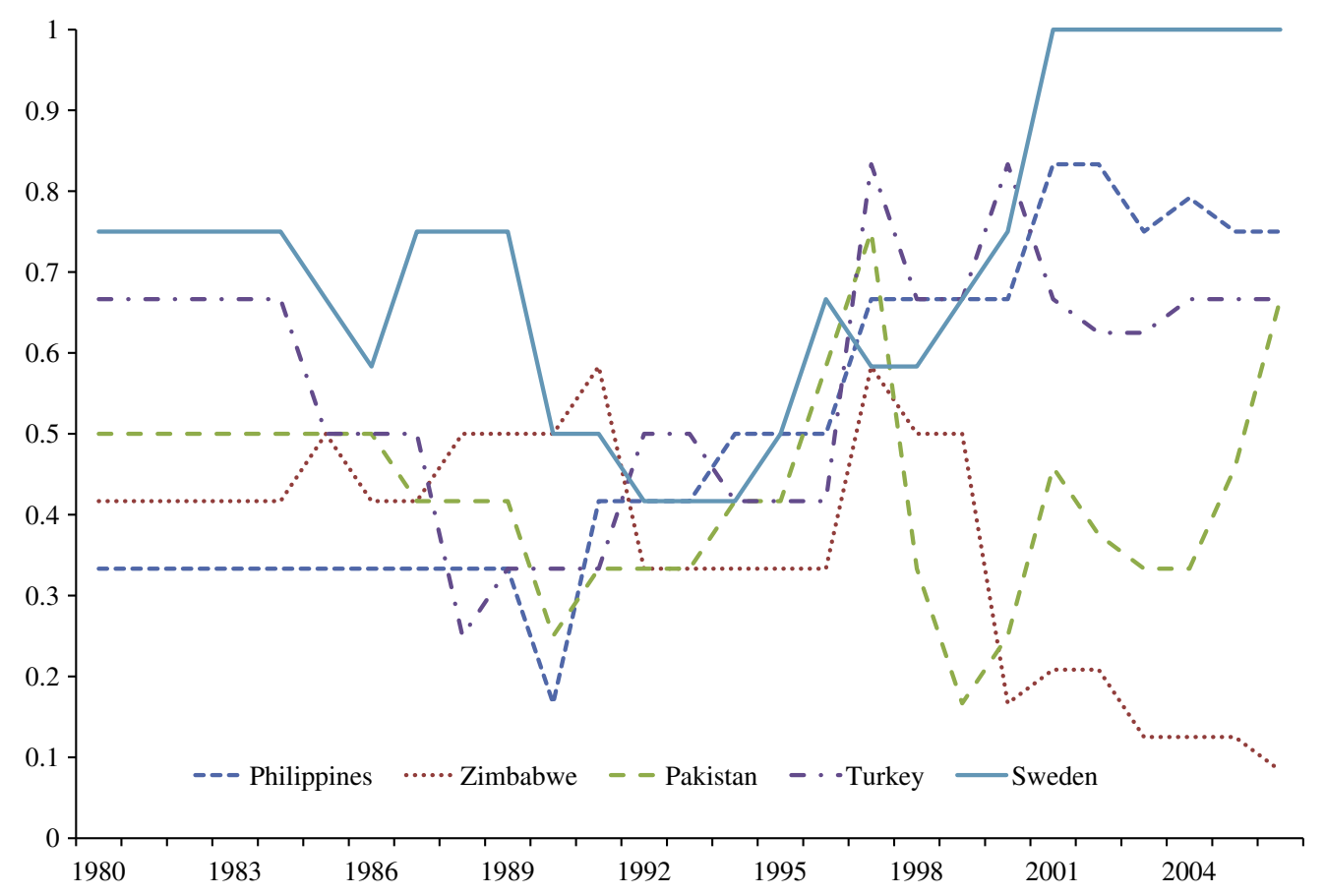

Figure 1. Investment profile through time.

variables are very persistent, so we include the lagged dependent variable in each specification. Second, we include time effects to potentially control for a general trend toward financial and institutional development. For some of the variables, we lose a number of countries so that time effects do exhaust many degrees of freedom. Therefore, we also comment on an alternative specification replacing time effects by one control variable, world GDP growth. The first specification, including the lagged independent variable and time effects, is reported on the left-hand side of Table 5 .

The specification reported in the two columns on the right adds a control variable that should assuage concerns about reverse causality and simultaneity. Liberalization may happen in countries with better developed financial systems and institutions or coincide with reforms directly targeting domestic financial development and institutions. Given that we do not have detailed information on reforms, we use the probit reported in Table 3 to derive a probability of liberalization, which is then added as a control to the regressions before. Hence, the coefficient on liberalization in the right-hand side of Table 5 can now be interpreted as the estimated effect of the "exogenous" component of liberalization, not linked to pure cross-sectional differences in current levels of development or institutional quality.

In addition, we have estimated (but do not report) regressions including a measure of exogenous growth opportunities available to each country constructed in Bekaert et al. (2007). This control variable mitigates the critique of the liberalization being timed to take advantage of unusually favorable growth opportunities (see Bekaert et al. (2005) for a lengthy discussion). The latter specification employs a smaller set of countries given limitations on the growth opportunities variable, but yields qualitatively similar results to the specifications reported in Table 4.

We now discuss the results in Table 5. The asterisks on the coefficients in Table 5 indicate that the variable in question is significant at the $5 \%$ level in a more parsimonious specification where the time effects are replaced by world GDP growth.
First, financial openness improves stock market liquidity, as measured by the drop in average zero daily returns. The coefficients across all specifications are negative but lack strong statistical significance. However, they become highly significant when world GDP growth replaces time effects. This is true for almost all the stock market development measures. Given that it is conceivable that there is a general trend toward better developed markets, not necessarily associated with openness to foreign investors, we should be cautious in interpreting these results. The financial openness effect on turnover is positive as expected, but loses statistical significance once we focus on the exogenous component of the liberalization. The size of the stock market (measured as the stock market capitalization to GDP ratio) also increases post-liberalization but not significantly, and once "endogenous" liberalization is controlled for, the effect weakens further. Price efficiency surprisingly deteriorates after financial openness. ${ }^{9}$

Turning to banking sector development, financial openness has a positive and significant effect on private credit to GDP. The results here confirm Chinn and Ito (2006), who find a link between broad capital market openness and measures of financial development in a regression framework that is similar to our first specification with some additional controls.

We now turn to our proposed institutional quality measures. Financial openness does not have a robust effect on our measures of either law and order or the quality of institutions when the world growth variable is used as a control. However, when we use time effects, the coefficients are statistically significant and mostly survive controlling for "endogenous" liberalization decisions. While not definitive, this does suggest that the mere presence of foreign investors may have wider beneficial effects on the institutions of a country. ${ }^{10}$ Financial openness also appears to significantly predict improvements in the investment profile, which is narrowly associated with law and regulations benefitting FDI. The effect disappears for "exogenous" equity liberalization. Finally, financial openness is robustly and significantly associated with improved macropolicies using both of our measures, perhaps reflecting a 
Table 5. The effect of financial openness on financial development, institutions, and macro-economic policies

\begin{tabular}{|c|c|c|c|c|}
\hline Dependent variable & $\begin{array}{l}\text { Capital account } \\
\text { openness }\end{array}$ & $\begin{array}{l}\text { Official equity market } \\
\text { liberalization }\end{array}$ & $\begin{array}{l}\text { Capital account openness } \\
\text { (includes probit) }\end{array}$ & $\begin{array}{l}\text { Official equity market liberalization } \\
\text { (includes probit) }\end{array}$ \\
\hline $\begin{array}{l}\text { Stock market development } \\
\text { Market illiquidity (log zero returns) }\end{array}$ & $\begin{array}{c}-0.0573^{*} \\
(0.0544) \\
{[45]}\end{array}$ & $\begin{array}{c}-0.0476^{*} \\
(0.0353) \\
{[47]}\end{array}$ & $\begin{array}{c}-0.0769^{*} \\
(0.0564) \\
0.0392 \\
(0.0453) \\
{[45]}\end{array}$ & $\begin{array}{c}-0.0463^{*} \\
(0.0360) \\
-0.0046 \\
(0.0352) \\
{[47]}\end{array}$ \\
\hline Turnover & $\begin{array}{c}0.0762^{*} \\
(0.0416) \\
\\
{[56]}\end{array}$ & $\begin{array}{c}0.0702^{*} \\
(0.0295) \\
{[60]}\end{array}$ & $\begin{array}{c}0.0558^{*} \\
(0.0423) \\
0.0428 \\
(0.0317) \\
{[55]}\end{array}$ & $\begin{array}{c}0.0424^{*} \\
(0.0294) \\
0.0627 \\
(0.0229) \\
{[59]}\end{array}$ \\
\hline MCAP/GDP & $\begin{array}{c}0.0925^{*} \\
(0.0592) \\
{[65]}\end{array}$ & $\begin{array}{c}0.0380^{*} \\
(0.0301) \\
\\
{[72]}\end{array}$ & $\begin{array}{c}0.0631^{*} \\
(0.0582) \\
0.1190 \\
(0.0272) \\
{[61]}\end{array}$ & $\begin{array}{c}-0.0098 \\
(0.0270) \\
0.1704 \\
(0.0282) \\
{[67]}\end{array}$ \\
\hline Price inefficiency & $\begin{array}{c}0.0900^{*} \\
(0.0130) \\
\\
{[44]}\end{array}$ & $\begin{array}{c}0.0455^{*} \\
(0.0092) \\
\\
{[46]}\end{array}$ & $\begin{array}{c}0.0936^{*} \\
(0.0138) \\
-0.0067 \\
(0.0146) \\
{[44]}\end{array}$ & $\begin{array}{c}0.0433^{*} \\
(0.0092) \\
0.0067 \\
(0.0074) \\
{[46]}\end{array}$ \\
\hline $\begin{array}{l}\text { Banking development } \\
\text { Private credit }\end{array}$ & $\begin{array}{c}0.0951^{*} \\
(0.0172) \\
{[78]}\end{array}$ & $\begin{array}{c}0.0535^{*} \\
(0.0107) \\
\\
{[96]}\end{array}$ & $\begin{array}{c}0.0748 \\
(0.0152) \\
0.0813 \\
(0.0155) \\
{[71]}\end{array}$ & $\begin{array}{c}0.0264 \\
(0.0097) \\
0.1276 \\
(0.0203) \\
{[81]}\end{array}$ \\
\hline $\begin{array}{l}\text { Institutions/corporate governance } \\
\text { Investment profile }\end{array}$ & $\begin{array}{c}0.1164^{*} \\
(0.0201) \\
\\
{[73]}\end{array}$ & $\begin{array}{c}0.0340^{*} \\
(0.0113) \\
\\
{[86]}\end{array}$ & $\begin{array}{c}0.0947^{*} \\
(0.0161) \\
0.0798 \\
(0.0201) \\
{[71]}\end{array}$ & $\begin{array}{c}-0.0082^{*} \\
(0.0080) \\
0.1154 \\
(0.0183) \\
{[81]}\end{array}$ \\
\hline Quality of institutions & $\begin{array}{c}0.0309 \\
(0.0078) \\
\\
{[73]}\end{array}$ & $\begin{array}{c}0.0187 \\
(0.0066) \\
\\
{[86]}\end{array}$ & $\begin{array}{c}0.0316 \\
(0.0081) \\
0.0039 \\
(0.0097) \\
{[71]}\end{array}$ & $\begin{array}{c}0.0130 \\
(0.0053) \\
0.0363 \\
(0.0085) \\
{[81]}\end{array}$ \\
\hline Law and order & $\begin{array}{c}0.0267 \\
(0.0133) \\
\\
{[73]}\end{array}$ & $\begin{array}{c}0.0267 \\
(0.0098) \\
\\
{[86]}\end{array}$ & $\begin{array}{c}0.0295 \\
(0.0130) \\
0.0470 \\
(0.0138) \\
{[71]}\end{array}$ & $\begin{array}{c}0.0130 \\
(0.0084) \\
0.0710 \\
(0.0153) \\
{[81]}\end{array}$ \\
\hline Macro-economic environment & $\begin{array}{c}0.0294^{*} \\
(0.0092) \\
\\
{[73]}\end{array}$ & $\begin{array}{c}0.0143^{*} \\
(0.0048) \\
\\
{[86]}\end{array}$ & $\begin{array}{c}0.0247^{*} \\
(0.0086) \\
0.0371 \\
(0.0074) \\
{[71]}\end{array}$ & $\begin{array}{c}0.0001^{*} \\
(0.0039) \\
0.0499 \\
(0.0086) \\
{[81]}\end{array}$ \\
\hline Log country credit rating & $\begin{array}{c}0.1210^{*} \\
(0.0275)\end{array}$ & $\begin{array}{c}0.0511^{*} \\
(0.0146)\end{array}$ & $\begin{array}{c}0.1298^{*} \\
(0.0273) \\
0.0635 \\
(0.0190) \\
{[71]}\end{array}$ & $\begin{array}{c}0.0440^{*} \\
(0.0136) \\
0.1235 \\
(0.0207) \\
{[81]}\end{array}$ \\
\hline
\end{tabular}

The dependent variable is each regression is provided in the left-most column. The variables of interest are separated into measures of stock market development, banking development, and institutions/corporate governance. We report the coefficient on financial openness defined as (1) Quinn's capital account openness indicator that takes a value between zero and one depending upon the intensity of the reported capital account openness and (2) the official liberalization indicator that takes a value of one when the equity market is liberalized, and zero otherwise. As controls, we employ the lagged dependent variable, year effects, and in the right-most columns the predicted probability of capital account or equity liberalization based on panel probit regressions of the relevant financial openness variables onto the contemporaneous trade/GDP, private credit/GDP, log country credit ratings, and the quality of institutions variables. For this second set of regressions, we also report, for comparison, the coefficient and standard error on this predicted probability of financial liberalization. The regressions cover 1980-2006. All standard errors (in parentheses) provide a correction for cross-sectional heteroskedasticity and account for the overlapping nature of the data. Given data limitations, the number of countries employed differs and is reported below each estimate (in brackets). An asterisk (*) indicates that the coefficient is statistically significant in the alternative regression where time effects are replaced by contemporaneous world GDP growth. 
disciplining effect of foreign investment. The one exception again is that the effect disappears for "exogenous" equity liberalization for the first "macro-economic environment" measure.

One interesting hypothesis to help interpret the significant factor productivity growth effects associated with financial openness is that financial openness may be part of a "Great Reversal" (Rajan \& Zingales, 2003) within countries, leading to generally better policies and institutions. Our results appear consistent with this hypothesis. We not only find direct, "exogenous" positive effects of financial openness, but also the coefficients on the probability of liberalization are typically significant, and that variable may indirectly proxy for simultaneous reforms.

As an additional test, we examine whether factor productivity growth increases through an improved efficiency of capital allocation. In the debate about how financial development contributes to economic growth, Wurgler (2000) and Fisman and Love (2004)'s work strongly suggest that financial development may improve capital allocation. Beck et al. (2000) demonstrate that factor productivity is positively related to the exogenous component of financial development. However, Bekaert et al. (2007) show that financial openness helps align exogenously available growth opportunities (GO) with actual growth, and that financial openness is more important than either financial development or the absence of financing constraints, stressed by Rajan and Zingales (1998). Bekaert et al. (2007) measure of exogenous growth opportunities essentially uses global valuation ratios for the industries in which a country specializes, and strongly predicts actual GDP growth. We use their framework to test whether the response of (aggregate) investment (from $t$ to $t+5$ ) to growth opportunities (measured at time $t$ ) is different in financially open economies. Hence, we are testing an interaction effect: improved domestic allocative efficiency would imply that investment growth responds more strongly to growth opportunities post-liberalization.

Table 6 reports the results. We consider three specifications each for capital account openness (top panel) and equity liberalization (bottom panel). The specification on the left is parsi- monious. Our regressors include the GO measure, the financial openness measure, and their interaction, in addition to time effects. In this regression, we find that neither growth opportunities nor financial openness has an independent effect on capital stock growth. This is not surprising. The coefficient on growth opportunities simply reflects that in closed economies, global growth opportunities do not lead to additional investment. Moreover, financial openness primarily serves to make countries respond better to growth opportunities: the interaction coefficients are positive and statistically significant. In the second specification, we also control for country-fixed effects. The interaction effects remains significant, but there is now also an independent effect of capital market openness on growth. In the third specification, we replace the countryfixed effects by the same initial GDP per capita measure used in Table 1 , and the effects remain robust, with now equity openness also generating independent effects. Adding more control variables does not change these conclusions. Not surprisingly, in all specifications, investment growth in closed countries fails to respond to the global growth opportunities available to their industries.

As a final "efficiency test," we examine whether a particular investment to GDP level generates more growth in financially open countries. To do so, we regress 5-year future growth on initial GDP per capita, year effects, financial openness, and the investment to GDP ratio, where the latter effect is split over "open" and "closed" countries. For capital account openness, we find that each percent of investment to GDP leads to a significantly larger growth response in open relative to closed countries. The increase in investment efficiency is about the same for equity market openness (on the order of 45-50 basis points of growth for a $20 \%$ investment to GDP ratio), but no longer statistically significant. Detailed results are available upon request.

\section{THRESHOLD EFFECTS}

Liberalization is associated with both capital stock and factor productivity growth. However, we only measure an

Table 6. Financial openness and allocative efficiency

\begin{tabular}{|c|c|c|c|}
\hline & Year effects & Year and country effects & Year effects and initial GDP \\
\hline Global growth opportunities & $\begin{array}{c}-0.0233 \\
(0.0148)\end{array}$ & $\begin{array}{c}-0.0106 \\
(0.0087)\end{array}$ & $\begin{array}{c}-0.0137 \\
(0.0139)\end{array}$ \\
\hline Global growth opportunities $\times$ capital account openness & $\begin{array}{c}0.0302 \\
(0.0112)\end{array}$ & $\begin{array}{c}0.0177 \\
(0.0092)\end{array}$ & $\begin{array}{c}0.0277 \\
(0.0117)\end{array}$ \\
\hline Capital account openness & $\begin{array}{c}-0.0007 \\
(0.0027)\end{array}$ & $\begin{array}{c}0.0161 \\
(0.0042)\end{array}$ & $\begin{array}{c}0.0207 \\
(0.0045)\end{array}$ \\
\hline Global growth opportunities & $\begin{array}{r}-0.0153 \\
(0.0113)\end{array}$ & $\begin{array}{r}-0.0072 \\
(0.0061)\end{array}$ & $\begin{array}{c}-0.0061 \\
(0.0118)\end{array}$ \\
\hline Global growth opportunities $\times$ official equity market liberalization & $\begin{array}{c}0.0161 \\
(0.0077)\end{array}$ & $\begin{array}{c}0.0135 \\
(0.0054)\end{array}$ & $\begin{array}{c}0.0175 \\
(0.0088)\end{array}$ \\
\hline Official equity market liberalization & $\begin{array}{c}0.0012 \\
(0.0022)\end{array}$ & $\begin{array}{r}-0.0016 \\
(0.0019)\end{array}$ & $\begin{array}{c}0.0076 \\
(0.0030)\end{array}$ \\
\hline
\end{tabular}

The dependent variable is the overlapping 5-year average growth rate of real per capita capital stock growth. We report the coefficients on exogenous growth opportunities available to each country, financial openness, and their interaction. In column (1), unreported year effects are also included. In column (2), unreported year and country-fixed effects are also included. Finally, in column (3) unreported year effects and the initial level of GDP are also included. Financial openness is defined as (1) Quinn's capital account openness indicator that takes a value between zero and one depending upon the intensity of the reported capital account openness and (2) the official liberalization indicator that takes a value of one when the equity market is liberalized, and zero otherwise. Given data limitations on the exogenous growth opportunities measure, the capital account openness regressions include 48 countries and the official equity market liberalization regressions include 50 countries. The regressions cover 1980-2006. We report coefficient estimates from pooled OLS regressions. All standard errors (in parentheses) provide a correction for cross-sectional heteroskedasticity and account for the overlapping nature of the data. 
average effect. It is important to examine the heterogeneity of the effect across different countries. Bekaert et al. (2005) document strong threshold effects in the overall GDP growth response to equity market liberalization. In exploring the effects of FDI on growth, Alfaro et al. (2004) and Alfaro et al. (2009) demonstrate positive interactions with the development of local financial markets. In Table 7, we investigate the potential for heterogeneity in the liberalization effects

Table 7. Heterogeneity of the capital stock and total productivity growth effects

\begin{tabular}{|c|c|c|c|c|c|c|c|c|c|}
\hline & \multicolumn{4}{|c|}{ Capital stock growth } & \multicolumn{4}{|c|}{ Total factor productivity } & \multirow{2}{*}{$\begin{array}{l}\text { No. of } \\
\text { countries }\end{array}$} \\
\hline & $\begin{array}{c}\text { From low } \\
\text { level }\end{array}$ & $\begin{array}{c}\text { From high } \\
\text { level }\end{array}$ & Direct effect & & $\begin{array}{c}\text { From low } \\
\text { level }\end{array}$ & $\begin{array}{c}\text { From high } \\
\text { level }\end{array}$ & Direct effect & & \\
\hline \multicolumn{10}{|c|}{ Panel A: Capital account openness } \\
\hline \multicolumn{10}{|l|}{ Financial sector } \\
\hline Private credit/GDP & $\begin{array}{c}0.0141 \\
(0.0024)\end{array}$ & $\begin{array}{c}0.0188 \\
(0.0030)\end{array}$ & $\begin{array}{c}0.0108 \\
(0.0028)\end{array}$ & ** & $\begin{array}{c}0.0058 \\
(0.0026)\end{array}$ & $\begin{array}{c}0.0135 \\
(0.0028)\end{array}$ & $\begin{array}{c}0.0021 \\
(0.0018)\end{array}$ & $* * *$ & 78 \\
\hline Turnover & $\begin{array}{r}-0.0010 \\
(0.0035)\end{array}$ & $\begin{array}{c}0.0237 \\
(0.0039)\end{array}$ & $\begin{array}{c}0.0089 \\
(0.0022)\end{array}$ & *** & $\begin{array}{c}0.0048 \\
(0.0037)\end{array}$ & $\begin{array}{c}0.0160 \\
(0.0038)\end{array}$ & $\begin{array}{c}0.0033 \\
(0.0017)\end{array}$ & $* * *$ & 66 \\
\hline MCAP/GDP & $\begin{array}{c}0.0143 \\
(0.0035)\end{array}$ & $\begin{array}{c}0.0118 \\
(0.0041)\end{array}$ & $\begin{array}{c}0.0007 \\
(0.0026)\end{array}$ & & $\begin{array}{c}0.0090 \\
(0.0031)\end{array}$ & $\begin{array}{c}0.0092 \\
(0.0038)\end{array}$ & $\begin{array}{c}-0.0051 \\
(0.0019)\end{array}$ & & 65 \\
\hline Antidirector rights & $\begin{array}{r}-0.0031 \\
(0.0042)\end{array}$ & $\begin{array}{c}0.0102 \\
(0.0049)\end{array}$ & $\begin{array}{r}-0.0104 \\
(0.0035)\end{array}$ & *** & $\begin{array}{c}0.0084 \\
(0.0038)\end{array}$ & $\begin{array}{c}0.0091 \\
(0.0035)\end{array}$ & $\begin{array}{c}0.0118 \\
(0.0037)\end{array}$ & & 46 \\
\hline Price inefficiency & $\begin{array}{c}0.0028 \\
(0.0050)\end{array}$ & $\begin{array}{c}-0.0098 \\
(0.0053)\end{array}$ & $\begin{array}{c}-0.0023 \\
(0.0058)\end{array}$ & *** & $\begin{array}{c}0.0090 \\
(0.0036)\end{array}$ & $\begin{array}{c}0.0036 \\
(0.0034)\end{array}$ & $\begin{array}{c}0.0092 \\
(0.0043)\end{array}$ & * & 46 \\
\hline \multicolumn{10}{|l|}{ Institutions } \\
\hline Quality of institutions & $\begin{array}{c}0.0039 \\
(0.0023)\end{array}$ & $\begin{array}{c}0.0232 \\
(0.0035)\end{array}$ & $\begin{array}{c}0.0090 \\
(0.0040)\end{array}$ & *** & $\begin{array}{c}0.0010 \\
(0.0031)\end{array}$ & $\begin{array}{c}0.0112 \\
(0.0042)\end{array}$ & $\begin{array}{c}0.0193 \\
(0.0045)\end{array}$ & $* *$ & 73 \\
\hline Investment profile & $\begin{array}{c}-0.0007 \\
(0.0022)\end{array}$ & $\begin{array}{c}0.0142 \\
(0.0027)\end{array}$ & $\begin{array}{c}0.0356 \\
(0.0039)\end{array}$ & $* * *$ & $\begin{array}{r}-0.0008 \\
(0.0027)\end{array}$ & $\begin{array}{c}0.0105 \\
(0.0033)\end{array}$ & $\begin{array}{c}0.0134 \\
(0.0057)\end{array}$ & $* *$ & 73 \\
\hline Law and order & $\begin{array}{c}0.0059 \\
(0.0024)\end{array}$ & $\begin{array}{c}0.0148 \\
(0.0038)\end{array}$ & $\begin{array}{c}0.0177 \\
(0.0033)\end{array}$ & *** & $\begin{array}{c}0.0011 \\
(0.0032)\end{array}$ & $\begin{array}{c}0.0087 \\
(0.0041)\end{array}$ & $\begin{array}{c}0.0161 \\
(0.0030)\end{array}$ & * & 73 \\
\hline Log country credit rating & $\begin{array}{c}-0.0044 \\
(0.0018)\end{array}$ & $\begin{array}{c}0.0181 \\
(0.0026)\end{array}$ & $\begin{array}{c}0.0169 \\
(0.0019)\end{array}$ & *** & $\begin{array}{c}0.0010 \\
(0.0027)\end{array}$ & $\begin{array}{c}0.0183 \\
(0.0033)\end{array}$ & $\begin{array}{c}0.0025 \\
(0.0023)\end{array}$ & $* * *$ & 74 \\
\hline \multicolumn{10}{|c|}{$\begin{array}{l}\text { Panel B: Official equity market liberalization } \\
\text { Financial sector }\end{array}$} \\
\hline Private credit/GDP & $\begin{array}{c}0.0100 \\
(0.0021)\end{array}$ & $\begin{array}{c}0.0131 \\
(0.0023)\end{array}$ & $\begin{array}{c}0.0061 \\
(0.0028)\end{array}$ & * & $\begin{array}{c}0.0011 \\
(0.0022)\end{array}$ & $\begin{array}{c}0.0100 \\
(0.0021)\end{array}$ & $\begin{array}{c}-0.0003 \\
(0.0016)\end{array}$ & $* * *$ & 96 \\
\hline Turnover & $\begin{array}{c}0.0006 \\
(0.0021)\end{array}$ & $\begin{array}{c}0.0119 \\
(0.0021)\end{array}$ & $\begin{array}{c}0.0113 \\
(0.0022)\end{array}$ & *** & $\begin{array}{c}0.0025 \\
(0.0021)\end{array}$ & $\begin{array}{c}0.0078 \\
(0.0019)\end{array}$ & $\begin{array}{c}0.0041 \\
(0.0017)\end{array}$ & ${ }^{* * *}$ & 73 \\
\hline MCAP/GDP & $\begin{array}{c}0.0099 \\
(0.0018)\end{array}$ & $\begin{array}{c}0.0085 \\
(0.0020)\end{array}$ & $\begin{array}{c}0.0005 \\
(0.0025)\end{array}$ & & $\begin{array}{c}0.0065 \\
(0.0014)\end{array}$ & $\begin{array}{c}0.0055 \\
(0.0018)\end{array}$ & $\begin{array}{r}-0.0046 \\
(0.0018)\end{array}$ & & 73 \\
\hline Antidirector rights & $\begin{array}{c}0.0027 \\
(0.0025)\end{array}$ & $\begin{array}{c}0.0115 \\
(0.0021)\end{array}$ & $\begin{array}{r}-0.0050 \\
(0.0021)\end{array}$ & $* * *$ & $\begin{array}{c}0.0071 \\
(0.0021)\end{array}$ & $\begin{array}{c}0.0086 \\
(0.0021)\end{array}$ & $\begin{array}{c}0.0098 \\
(0.0023)\end{array}$ & & 47 \\
\hline Price inefficiency & $\begin{array}{c}0.0082 \\
(0.0030)\end{array}$ & $\begin{array}{r}-0.0021 \\
(0.0027)\end{array}$ & $\begin{array}{r}-0.0007 \\
(0.0055)\end{array}$ & $* * *$ & $\begin{array}{c}0.0049 \\
(0.0024)\end{array}$ & $\begin{array}{c}0.0023 \\
(0.0023)\end{array}$ & $\begin{array}{c}0.0077 \\
(0.0043)\end{array}$ & * & 46 \\
\hline \multicolumn{10}{|l|}{ Institutions } \\
\hline Quality of institutions & $\begin{array}{c}0.0083 \\
(0.0026)\end{array}$ & $\begin{array}{c}0.0138 \\
(0.0023)\end{array}$ & $\begin{array}{c}0.0083 \\
(0.0041)\end{array}$ & ${ }^{* *}$ & $\begin{array}{c}0.0018 \\
(0.0025)\end{array}$ & $\begin{array}{c}0.0064 \\
(0.0024)\end{array}$ & $\begin{array}{c}0.0164 \\
(0.0044)\end{array}$ & & 86 \\
\hline Investment profile & $\begin{array}{c}0.0010 \\
(0.0011)\end{array}$ & $\begin{array}{c}0.0149 \\
(0.0031)\end{array}$ & $\begin{array}{c}0.0327 \\
(0.0043)\end{array}$ & *** & $\begin{array}{r}-0.0013 \\
(0.0018)\end{array}$ & $\begin{array}{c}0.0086 \\
(0.0025)\end{array}$ & $\begin{array}{c}0.0155 \\
(0.0053)\end{array}$ & ${ }^{* * *}$ & 86 \\
\hline Law and order & $\begin{array}{c}0.0094 \\
(0.0029)\end{array}$ & $\begin{array}{c}0.0115 \\
(0.0017)\end{array}$ & $\begin{array}{c}0.0134 \\
(0.0033)\end{array}$ & & $\begin{array}{c}0.0030 \\
(0.0023)\end{array}$ & $\begin{array}{c}0.0062 \\
(0.0027)\end{array}$ & $\begin{array}{c}0.0136 \\
(0.0033)\end{array}$ & & 86 \\
\hline Log country credit rating & $\begin{array}{r}-0.0042 \\
(0.0018)\end{array}$ & $\begin{array}{c}0.0113 \\
(0.0022)\end{array}$ & $\begin{array}{c}0.0213 \\
(0.0014)\end{array}$ & $* * *$ & $\begin{array}{r}-0.0027 \\
(0.0014)\end{array}$ & $\begin{array}{c}0.0094 \\
(0.0020)\end{array}$ & $\begin{array}{c}0.0056 \\
(0.0018)\end{array}$ & ${ }^{* * *}$ & 73 \\
\hline
\end{tabular}

For each interaction variable, we separately conduct regressions that have the 5-year average growth rate of the real capital stock and total factor productivity growth as the dependent variables. We include in the regressions the same control variables presented in Table 1 . We estimate interaction effects between financial openness and the financial sector and quality of institutions variables. We report the associated impact of growth from openness for a country with a low level (below the median of the associated interaction variable) and with a high level (above the median of the associated interaction variable). We also allow for a direct effect on growth associated with the interaction variable. In Panel A, we report the effect where financial openness is defined as Quinn's capital account openness indicator that takes a value between zero and one depending upon the intensity of the reported capital account openness. In Panel B, financial openness is defined as the official liberalization indicator that takes a value of one when the equity market is liberalized, and zero otherwise. Given data limitations, the regressions employ varied numbers of countries which are provided in the right-most column. We report coefficient estimates from pooled OLS regressions. The regressions cover 1980-2006. All standard errors (in parentheses) provide a correction for cross-sectional heteroskedasticity and account for the overlapping nature of the data. Last, we provide the significance of a Wald test, for which the null hypothesis is that the high-low effects are equivalent.

${ }_{* *}^{*} 10 \%$ Significance level.

** $5 \%$ Significance level.

*** $1 \%$ Significance level. 
associated with the two growth channels, for various country characteristics. Panel A focuses on the capital account openness measure and Panel B on the official equity market liberalization.

We measure the heterogeneity across countries in the financial openness effect by breaking up the indicator variable into two pieces:

$$
\begin{aligned}
y_{i, t+5, t}= & \beta Q_{i, \text { start }}+\gamma^{\prime} \mathbf{X}_{i, t}+\alpha_{L} \operatorname{Lib}_{i, t}^{\text {Low }}+\alpha_{H} \operatorname{Lib}_{i, t}^{\text {High }} \\
& +\delta \operatorname{Char}_{i, t}+\epsilon_{i, t+5,5}
\end{aligned}
$$

where $y_{i, t+5, t}$ represents either the 5-year capital stock or total factor productivity growth, Lib ${ }_{i, t}^{\text {Low }}$ denotes the openness variable for countries that falls below the median value for certain country characteristics, and $\mathrm{Lib}_{i, t}^{\mathrm{High}}$ is the analogous definition for countries that fall above the median value. The regression also includes the "own-effect" of the characteristic, which is denoted by $\mathrm{Char}_{i, t}$. We report the coefficients on the high and low characteristic indicators as well as a Wald test of the null hypothesis that the coefficients are not significantly different from one another. We also report the coefficient on the own effect.

We estimate a different regression for each country characteristic. This approach does not exploit the continuous nature of the country characteristics measures, and does not allow us to extract partial effects from different, correlated country characteristics. Unfortunately, the various country characteristics are available for different sets of countries, and they are very highly correlated, especially when interaction terms are considered. This makes a multivariate analysis with continuous interaction effects impossible. Instead, our analysis is easy to interpret and does not generate much correlation between the independent variables.

We consider two categories of interaction variables: financial sector variables (private credit/GDP, equity market turnover, equity market capitalization/GDP, antidirector rights, and the price inefficiency measure) and quality of institutions variables (the ICRG quality of institutions measure, the investment profile, law and order, and the country credit rating). All of these variables are further described in Tables A.1 and A.2.

We focus the discussion on the capital account openness measure. The regressions suggest significant heterogeneity in the capital growth regressions with respect to eight of the nine variables considered. The countries with a "high" level of the characteristic (better than average financial development and better quality institutions) have a significantly higher capital growth response to liberalization than the countries with a "low" level of the characteristic. For example, the quality of institutions is important for capital stock growth in both "low" and "high" Quality of Institutions countries. However, the coefficient is six times larger for countries that have high quality institutions. While this is perhaps not surprising, it is definitely conceivable that countries with poor institutions and financial development may experience the largest drop in the cost of capital and generate large investment responses. For one variable, price inefficiency, we expect negative direct and interaction effects. In seven out of nine cases, the direct effect is positive (or negative in the price inefficiency case) and statistically significant.

The total factor productivity regressions are also suggestive of heterogeneity; however, the evidence is somewhat weaker. Similar to the results for capital stock growth, the coefficients on the "high" level of the variable are generally greater than the coefficients on the "low" level of the variable (and smaller for the price inefficiency variable), and the high-level coeffi- cients are mostly statistically significant. However, the difference between the two coefficients is now only significant in seven cases and significant at the 1\% level in only three cases. For example, for Quality of Institutions, the coefficient in the "low" countries is not significantly different from zero. The coefficient for the "high" countries is significant and 11 times greater than the point estimate for the low countries, but the difference is only significant at the 5\% level. The results in $\mathrm{Pa}-$ nel $\mathrm{B}$ of Table 7 for equity market liberalization are qualitatively similar, but statistically slightly weaker.

Our analysis shows that the particular characteristics of a country often influence the capital stock and factor productivity response to financial liberalization. Much more work is needed to disentangle how such interaction effects really arise. Gupta and Yuan (2009) provide some perspective on the positive interaction effect with financial development for equity market liberalization using industry data. They find that liberalization relaxes financing constraints and stimulates the creation of new firms only in countries that are relatively well financially developed. They also provide some direct evidence that regulatory barriers and institutional frictions prevent certain firms (industries) to take full advantage of liberalization. It is conceivable that it is simply optimal for countries not to open up in the early stages of financial development, for example, because informal mechanisms to allocate capital work well at that stage (see, e.g., Allen, Qian, \& Qian, 2005; Giannetti \& Yu, 2008).

\section{LIBERALIZATION AND CRISES}

An often-heard critique of financial liberalization is that it increases the macro-economic vulnerability of countries and the probability of a financial crisis (see Stiglitz, 2000). An extensive literature on the effects of liberalization on risk sharing and macro-volatility finds mixed results (see Bekaert, Harvey, \& Lundblad, 2006; Fratzscher \& Imbs, 2009; Kose, Prasad, \& Terrones, 2003), although the bulk of the evidence does not support a strong increase in real volatility post liberalization. Here, we focus on the interaction between liberalization and banking sector crises. While such crises may not necessarily lead to a permanent output loss (see Ranciere et al. (2008) for an interesting discussion on the effect of crises on long-term growth), they often lead to a dramatic temporary output loss. The crisis measure we use is derived from the dates for banking crises provided by Caprio and Klingebiel (2005). Our results are summarized in Table 8.

The first exercise we conduct is to simply include the crisis dummy contemporaneously with the dependent variable in our standard growth regression from Table 1. In Panel A, the crisis coefficient indicates the average annual loss in GDP growth during a crisis year. The estimates are around $1 \%$ of GDP per year. The inclusion of this variable does not significantly affect the coefficients associated with financial openness. This is inconsistent with the critique that financial liberalizations may take place after a crisis and hence that the growth effect is biased because of the crisis years occurring just before the reforms.

However, it is still possible that financial openness interacts with crises in other ways. The second set of results also includes an interaction effect between crises and openness. Interestingly, the results suggest that the output cost of a crisis is larger in open countries. The effect is the largest for capital market openness (estimated to be around 1.5\%) but only borderline significant. For equity market liberalization, the effect is not significant. Nevertheless, it does appear that there may 
Table 8. Financial openness and crises

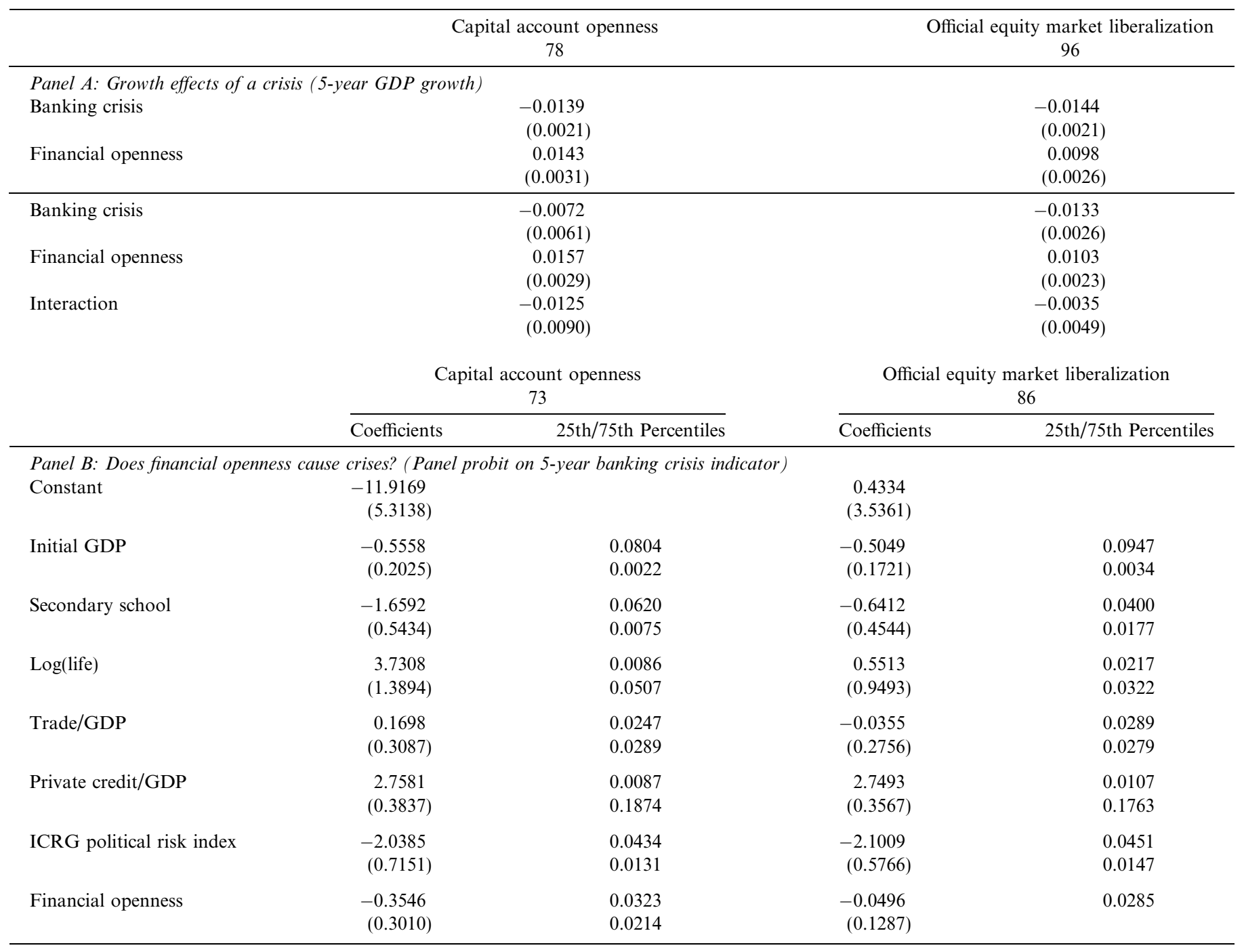

In Panel A, the dependent variable is the overlapping 5-year average growth rate of real per capita gross domestic product (GDP). The regressions include the set of standard control variables employed in Table 1. We report the coefficient on financial openness defined as (1) Quinn's capital account openness indicator that takes a value between zero and one depending upon the intensity of the reported capital account openness and (2) the official liberalization indicator that takes a value of one when the equity market is liberalized, and zero otherwise. We report the GDP growth effect associated with a contemporaneous banking sector crisis as identified by Caprio and Klingebiel, as well as an interaction effect between financial openness and banking sector crises. Given data limitations, the capital account openness regressions include 78 countries and the official equity market liberalization regressions include 96 countries. We report coefficient estimates from pooled OLS regressions. The regression covers 1980-2006. All standard errors (in parentheses) provide a correction for cross-sectional heteroskedasticity and account for the overlapping nature of the data. In Panel B, the dependent variable in a panel probit estimation is a $0 / 1$ indicator measuring the incidence of a banking sector crisis over the subsequent 5 -years. We include the standard control variables, the ICRG's measure of political risk, and our two measures of financial openness. We report both the coefficient estimates and, in the second column, a measure of the economic significance of the effects. In particular, we provide two specific predicted crisis probabilities where we evaluate all the variables at their medians except the variable in question, which is evaluated at, respectively, the $25 \%$ and $75 \%$ percentiles in its overall distribution.

be a cost to liberalizations in the form of larger crises. However, it is important to realize that the temporary output loss due to crises is outweighed in our sample by the positive growth effects of liberalization. A crisis lasts on average 3.5 years, so the estimate of the total output loss of a crisis in a financially open country varies between $6.50 \%$ (capital account openness) and $5.88 \%$ (equity market openness). However, the output gain of liberalization is to a certain extent permanent. A temporary growth spurt after liberalization of about 5 years with the per annum effects reported in Table 8 would suffice to offset the output loss induced by a crisis.

These results already suggest that many crises happened post-liberalization. A case in point is the South-East Asian cri- sis that happened 5-6 years after liberalization in a number of countries. This raises the possibility that liberalizations cause or help cause crises. In Panel B, we report the results of a panel probit analysis. The left-hand side variable is a dummy variable that takes on the value of one if there is a crisis over the next 5 years. The independent variables are measured at the beginning of the 5-year period. We only include closed or liberalizing countries in this sample, and the independent variables are the ones employed in the regressions reported in Table 1 plus the ICRG political risk index.

We find a number of significant predictors of a banking sector crisis. First, larger levels of initial per capita GDP, secondary school enrollment, and life expectancy are all strongly 
associated with a reduced probability of a crisis in the capital account specification, but in the equity market specification only initial GDP remains significant among these variables. Second, larger scores for ICRG's political risk index (where larger numbers denote higher levels of safety) are also significantly associated with reduced crisis probabilities. The second column provides an interpretation of the economic significance of the effects by reporting two specific predicted crisis probabilities. In particular, we evaluate all the variables at their medians except the variable in question, which is evaluated at, respectively, the $25 \%$ and $75 \%$ percentiles in its overall distribution. Clearly, of the explanatory variables discussed so far, economic development, measured using initial GDP per capita, generates the largest spread in crisis probabilities.

There are two sets of surprising results that are of considerable interest. First, there is no reliably significant relationship between financial openness and the probability of a banking sector crisis. The point estimates for both measures are negative. For capital account openness, the coefficient is more than one standard error below zero. An alternative way to state the result is that capital controls do not help avert crises. This result is consistent with Glick and Hutchison's (2005) analysis of the effect of capital controls on exchange rate stability, finding that, if anything, they appear to increase the vulnerability of economies to speculative attacks.

Second, there is a significantly positive relationship between the private credit to GDP ratio and the probability of a banking sector crisis, which is economically very important as well. ${ }^{11}$ Our evidence suggests that high levels of leverage reflected in the ratio of private credit to GDP increase the risk of a crisis. That is, leverage - not openness - is driving the crisis probabilities.

\section{CONCLUSIONS}

Our work fits into a growing research area that investigates the link between financial openness (both capital account and equity market) and productivity. We dissect growth into two channels: capital stock growth and total factor productivity growth. In contrast to the work of Bonfiglioli (2008), we find that financial openness positively impacts both of these channels, but has a greater impact on factor productivity than investment. Hence, we are able to reconcile the relatively large GDP growth response to financial openness and the relatively modest increase in investment. In recent work, Kose, Prasad, and Terrones (2009) also find a positive effect on productivity. Bonfiglioli (2008) and Kose et al. (2009) also find productivity effects despite using a coarse measure of capital account openness. We push the story further, offering three additional insights.

First, we investigate whether the growth effects are permanent or temporary. The neo-classical model of growth suggests a temporary effect. Our results show both temporary and permanent effects both in the growth of the capital stock and total factor productivity. We provide some insights into the channels of these permanent effects, showing that financial openness is associated with future improvements in financial development, institutional quality, and macro-economic policies. These results are mostly, but not always, robust to controlling for simultaneous reforms, but are somewhat sensitive to how we control for time effects. This insight seems particularly germane to policy makers considering regulatory reforms.

Second, we show that both capital stock and productivity growth display heterogeneous effects. Intuitively, it does not make sense that all countries respond in the same fashion to a financial liberalization - whether in the capital account or the equity market. Our analysis shows that the initial country-specific characteristics of the financial sector and the quality of institutions significantly drive the size of the growth response in both capital stock and factor productivity. The pre-existing environment into which reforms are introduced is critical.

Finally, we address the currently relevant question of whether financial liberalization is worth it if it renders a country more sensitive to banking crises. When we control for banking crises, the financial openness effect in our growth regression remains robust. This establishes that recovery from

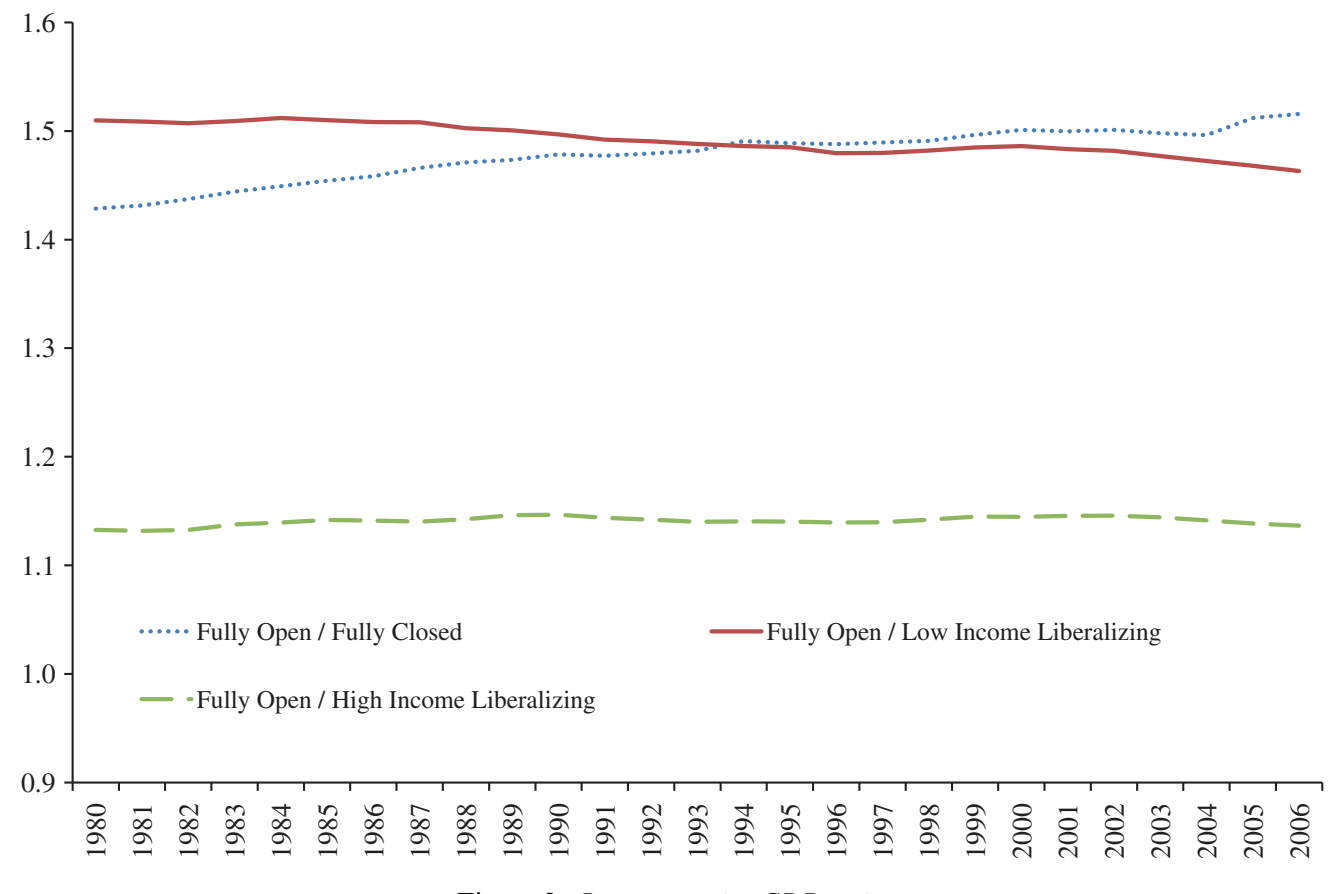

Figure 2. Log per capita GDP ratios. 
banking crises is not somehow inducing a spurious relation between openness and growth. More importantly, a panel probit analysis shows that financial openness does not significantly influence the probability of a banking crisis (and the point estimates are, in fact, negative). Indeed, our probability of crisis model points to the leverage that the banking sector employs as a critical determinant of banking crises, which we intend to explore in future work.

Our work, together with the mounting micro-oriented evidence as in Chari and Henry (2008), Gupta and Yuan (2009) and Mitton (2006), is consistent with the notion that financial openness has indeed improved growth prospects for most countries. Ultimately, firm-specific evidence should yield more powerful tests and finer detail on how productivity is enhanced through openness.

We want to end with an additional "big picture" empirical result. The main reason to focus on factor productivity growth is Gourinchas and Jeanne (2006)'s observation that to close the development gap, financial openness would have to raise factor productivity. But, what happened to the development gap during our sample period? In Figure 2, we provide a tantalizing, but depressing answer. We examine the average GDP per capita (in logs) of four country groups: countries that never opened, liberalizing countries with a relatively high GDP per capita in 1980, liberalizing countries with a relatively low GDP per capita, and countries that were already financially open in 1980 . We show the evolution over time of the ratio of per capita GDP of the always open countries to the per capita GDP of the first three groups. We stratify the liberalizing economies in terms of initial GDP because, as a group, their development level was higher than that of the always closed countries.

Figure 2 shows that the income of the low income liberalizing countries is actually lower than that of the always closed countries. Liberalizing countries as a group have closed a bit of the gap. On average, the ratio went from 1.51 in 1980 to 1.46 in 2005 , where most of the convergence is actually coming from the lower income countries. However, the closed countries have diverged: while the open countries were 1.42 times richer in 1980, they are now 1.52 times richer. This evolution also means that liberalization has in fact contributed to increased cross-sectional dispersion of per capita GDPs, with the main contributor being the growing divergence between poor, closed countries and open countries.

We examine the cross-sectional dispersion by estimating the following regression:

$\operatorname{Disp}_{t}=\alpha_{0}+\alpha_{1}^{\prime} \mathbf{X}_{t}+\eta_{t}$

where $\operatorname{Disp}_{t}$ is the cross-sectional variance of log GDP per capita across all countries for each year. $\mathbf{X}_{t}$ is a vector of explanatory variables including: the time-series variance of world GDP growth (taken as a rolling 5-year standard deviation of world GDP growth), the percentage of countries undergoing a banking crisis in that year, the average level of the trade to GDP ratio, and the spread between the $\log$ per capita GDP levels for countries that are either fully open or fully closed throughout our sample. Finally, to examine the role for financial openness, we include the percentage of countries with either an open capital account or equity market. Of these potential explanatory variables, only the spread between GDP per capita for open and closed countries and the level of financial openness, using either measure, are statistically significant. Both effects are positive, suggesting that financial openness has indeed contributed to higher cross-sectional income dispersion over time. In sum, in the parlance of the neo-classical growth theory, the globalization process has led to some level convergence but also to sigma divergence.

In conclusion, our results on the growth effects are not uniformly positive. We find a near-permanent effect of financial openness on factor productivity, but, so far, income levels in liberalizing countries are still far removed from industrialized country levels. Moreover, the alarming income divergence for the poorest countries poses a huge challenge for development economics that globalization by itself cannot resolve, especially since we also document strong threshold effects in Section 4.

\section{NOTES}

1. On the link between productivity and financial development, see Jeong and Townsend (2007) who show that total factor productivity growth can come about by financial deepening and an expansion of credit (using data from Thailand); Hsieh and Klenow (2009) who provide micro evidence on capital mis-allocation in China and India relative to the United States; Levine and Zervos (1998) who show that stock market development improves factor productivity; and Peress (2008) who proposes a model that links financial development and technological progress.

\section{See, for instance, Kaminsky and Reinhart (1999).}

3. See also Eichengreen (2001). Unlike Rodrik's claim, these results remain robust to the inclusion of institutional quality variables, as we show below. Henry (2007) discusses some other problems with Rodrik's empirical approach.

4. In the presence of Wacziarg and Welch's trade liberalization indicator, the capital account and equity openness effects are somewhat smaller, but are still near $1 \%$ per annum and highly statistically significant. The trade liberalization effect itself is statistically significant and around 50-70 basis points per annum in magnitude for GDP, capital stock, or total factor productivity growth.
5. For our full 96 country sample, the inclusion of bothcountry and time indicators leads to a poorly behaved variance-covariance matrix given the dimensionality of the system. For this reason, we employ instead world GDP growth as an alternative control variable for temporal effects.

6. We do not report the results to conserve space and because the use of the measure restricts our sample of countries.

7. These concerns are therefore much more valid when de facto, as opposed to de jure, financial integration is considered: capital may flow to "productive" countries.

8. We also consider an alternative probit specification just for those countries that either liberalize in-sample or never liberalize. This specification is more in line with traditional "treatment" interpretations used in this literature, and yields similar results.

9. Griffin, Kelly, and Nardari (2010) discuss how time-variation in this measure is sometimes difficult to interpret. In contrast, Bailey, Bae, and Mao (2006) show that financial openness improves the information environment. For instance, analyst coverage and value-added by analysts increase with openness, partly due to the increased presence and activity of foreign analysts. 
10. For example, Desai and Moel (2008) discuss a particular case where the government of the Czech Republic compensated a foreign investment unit following significant losses associated with poor corporate governance. More generally, Leuz, Lins, and Warnock (2009) find that foreigners invest less in firms that reside in countries with poor outsider protection, disclosure, and governance. Choi, Lee, and Park (2007) provide a specific example of a foreign-financed activist fund that directly pushes corporate governance reforms in Korea.

11. Bonfiglioli (2008) also finds a positive link between private credit to GDP and crises; she also finds a limited role for financial liberalization in explaining crises in developed countries.

\section{REFERENCES}

Acemoglu, D., Johnson, S., \& Robinson, J. (2001). The colonial origins of comparative development: An empirical investigation. American Economic Review, 91(5), 1369-1401.

Alfaro, L., Chanda, A., Kalemli-Ozcan, S., \& Sayek, S. (2004). FDI and economic growth: The role of local financial markets. Journal of International Economics, 64(1), 113-134.

Alfaro, L., Kalemli-Ozcan, S., \& Sayek, S. (2009). FDI, productivity, and financial development. The World Economy, 32(1), 111-135.

Allen, F., Qian, J., \& Qian, M. (2005). Law, finance, and economic growth in China. Journal of Financial Economics, 77(1), 57-116.

Bailey, W., Bae, K.-H., \& Mao, M. (2006). Stock market liberalization and the information environment. Journal of International Money and Finance, 25(3), 404-428.

Barro, R. J. (1997a). Determinants of economic growth. Cambridge, MA MIT Press.

Barro, R. J. (1997b). Determinants of economic growth: A cross-country empirical study. Discussion paper 579. Harvard Institute for International Development.

Barro, R. J., \& Sala-i-Martin, X. (1995). Economic growth. New York, NY: McGraw-Hill.

Beck, T., Levine, R., \& Loayza, N. (2000). Finance and sources of growth. Journal of Financial Economics, 58(1-2), 261-300.

Bekaert, G. (1995). Market integration and investment barriers in emerging equity markets. World Bank Economic Review, 9(1), 75-107.

Bekaert, G., \& Harvey, C. R. (2000). Foreign speculators and emerging equity markets. Journal of Finance, 55(2), 565-614.

Bekaert, G., \& Harvey, C. R. (2005). Chronology of important financial, economic and political events in emerging markets. $<$ http://www.duke.edu/ charvey/chronology.htm $>$.

Bekaert, G., Harvey, C. R., \& Lundblad, C. (2001). Does financial liberalization spur growth? NBER working paper \#8245.

Bekaert, G., Harvey, C. R., \& Lundblad, C. (2005). Does financial liberalization spur growth?. Journal of Financial Economics, 77(1), $3-56$

Bekaert, G., Harvey, C. R., \& Lundblad, C. (2006). Growth volatility and financial liberalization. Journal of International Money and Finance, 25(3), 370-403.

Bekaert, G., Harvey, C. R., \& Lundblad, C. (2007). Liquidity and expected returns: Lessons from emerging markets. Review of Financial Studies, 20(6), 1783-1831.

Bekaert, G., Harvey, C. R., Lundblad, C., \& Siegel, S. (2007). Growth opportunities and market integration. Journal of Finance, 62(3), 1081-1137.

Bils, M., \& Klenow, P. (2000). Does schooling cause growth?. American Economic Review, 90(5), 1160-1183.

Bonfiglioli, A. (2008). Financial integration, productivity and capital accumulation. Journal of International Economics, 76(2), 337-355.

Borensztein, E., De Gregorio, J., \& Lee, J. W. (1998). How does foreign investment affect growth?. Journal of International Economics, 45(1), 115-135

Bosworth, B., \& Collins, S. (2003). The empirics of growth: An update. Brookings papers on economic activity (pp. 113-206).

Caprio, G., Jr., \& Klingebiel, D. (2005). Bank insolvencies: Cross-country experience. Unpublished working paper 1620. Washington, DC: World Bank.

Chari, A., \& Henry, P. B. (2008). Firm-specific information and the efficiency of investment. Journal of Financial Economics, 87(3), 636-655.

Chinn, M., \& Ito, H. (2006). What matters for financial development? Capital controls, institutions, and interactions. Journal of Development Economics, 81(1), 163-192.
Choi, J., Lee, D. K., \& Park, K. S. (2007). Corporate governance and firm value: Endogeneity-free evidence from Korea. Working paper.

Desai, M., \& Moel, A. (2008). Czech mate: Expropriation and investor protection in a converging world. Review of Finance, 12(1), 221-251.

Edison, H., Levine, R., Ricci, L. A., \& Slok, T. M. (2002). International financial integration and economic growth. Journal of International Money and Finance, 21(6), 749-776.

Edison, H., \& Warnock, F. (2003). A simple measure of the intensity of capital controls. Journal of Empirical Finance, 10(1-2), 81-104.

Edwards, S. (2001). Capital mobility and economic performance: Are emerging economies different. In H. Siebert (Ed.), The Worlds new financial landscape: Challenges for economic policy (pp. 219-244). Berlin: Springer.

Eichengreen, B. (2001). Capital account liberalization: What do the crosscountry studies tell us?. World Bank Economic Review, 15(3), 341-366.

Errunza, V., \& Losq, E. (1985). International asset pricing under mild segmentation: Theory and test. Journal of Finance, 40(1), 105-124.

Ferreira, M., \& Matos, P. (2008). The colors of investors' money: The role of institutional investors around the world. Journal of Financial Economics, 88(3), 499-533.

Fine, B. (2002). Economics imperialism and the new development economics as Kuhnian paradigm shift?. World Development, 30(12), 2057-2070.

Fisman, R., \& Love, I. (2004). Financial development and intersector allocation: A new approach. Journal of Finance, 59(6), 2785-2807.

Fratzscher, M., \& Imbs, J. (2009). Risk sharing, finance and institutions in international portfolios. Journal of Financial Economics, 94(3), $428-447$.

Galindo, A., Schiantarelli, F., \& Weiss, A. (2007). Does financial liberalization improve the allocation of investment? Journal of Development Economics, 83, 562-587.

Giannetti, M., \& Yu, X. (2008). Favoritism or markets in capital allocation? Working paper.

Glick, R., \& Hutchison, M. (2005). Capital controls and exchange rate instability in developing countries. Journal of International Money and Finance, 24(3), 387-412.

Gollin, D. (2002). Getting income shares right. Journal of Political Economy, 110(2), 458-474.

Gourinchas, P., \& Jeanne, O. (2006). The elusive gains from international financial integration. Review of Economic Studies, 73(3), 715-741.

Griffin, J., Kelly, P., \& Nardari, F. (2010). Are emerging markets more profitable? Implications for comparing weak and semi-strong form efficiency. Review of Financial Studies, in press.

Gupta, N., \& Yuan, K. (2009). On the growth effect of stock market liberalizations. Review of Financial Studies, 22(11), 4715-4752.

Hall, R., \& Jones, C. (1999). Why do some countries produce so much more output per worker than others. The Quarterly Journal of Economics, 114(1), 83-116.

Henry, P. B. (2000). Stock market liberalization, economic reform, and emerging market equity prices. Journal of Finance, 55(2), 529-564

Henry, P. B. (2003). Capital account liberalization, the cost of capital, and economic growth. American Economic Review, 93(2), 91-96.

Henry, P. B. (2007). Capital account liberalization: Theory, evidence and speculation. Journal of Economic Literature, 45(4), 887-935.

Hsieh, C., \& Klenow, P. (2009). Misallocation and manufacturing TFP in China and India. The Quarterly Journal of Economics, 124(4), $1403-1448$.

Jeong, H., \& Townsend, R. (2007). Sources of TFP growth: Occupational choice and financial deepening. Economic Theory, 32(1), 179-221.

Johnson, S., \& Mitton, T. (2003). Cronyism and capital controls: Evidence from Malaysia. Journal of Financial Economics, 67(2), 351-382. 
Kaminsky, G. L., \& Reinhart, C. (1999). The twin crises: The causes of banking and balance of payments problems. American Economic Review, 89(3), 473-500.

King, R., \& Levine, R. (1993). Finance and growth: Schumpeter might be right. The Quarterly Journal of Economics, 108(3), 717-738.

Klein, M. W. (2003). Capital account openness and the varieties of growth experience. Unpublished working paper 9500. Cambridge, Massachusetts: National Bureau of Economic Research.

Kose, M., Prasad, E., \& Terrones, M. (2003). Financial integration and macroeconomic volatility. IMF Staff Papers, 50, 119-142.

Kose, M., Prasad, E., \& Terrones, M. (2009). Does openness to international flows raise productivity growth?. Journal of International Money and Finance, 28(4), 554-580.

La Porta, R., Lopez-de-Silanes, F., Shleifer, A., \& Vishny, R. W. (1998). Law and finance. Journal of Political Economy, 106, 1113-1155.

Lesmond, D. A. (2005). The costs of equity trading in emerging markets. Journal of Financial Economics, 77(2), 411-452.

Lesmond, D., Ogden, J. P., \& Trzcinka, C. (1999). A new estimate of transaction costs. Review of Financial Studies, 12, 1113-1141.

Leuz, C., Lins, K., \& Warnock, F. (2009). Do foreigners invest less in poorly governed firms?. Review of Financial Studies, 22(8), 3245-3285.

Levine, R., \& Zervos, S. (1998). Stock markets, banks, and economic growth. American Economic Review, 88(3), 537-558.

Mitton, T. (2006). Stock market liberalization and operating performance at the firm level. Journal of Financial Economics, 81(3), 625-647.

Morck, R., Yeung, B., \& Yu, W. (2000). The information content of stock markets: Why do emerging markets have synchronous stock price movements?. Journal of Financial Economics, 58(1-2), 215-260.

Newey, W., \& West, K. (1987). A simple, positive semi-definite, heteroskedasticity and autocorrelation consistent covariance matrix. Econometrica, 55(3), 703-708.

Obstfeld, M. (1994). Risk-taking, global diversification, and growth. American Economic Review, 84, 1310-1329.

Ortega, D., \& Rodrguez, F. (2006). Are capital shares higher in poor countries? Evidence from industrial surveys. Wesleyan economics working papers.

Peress, J. (2008). Learning about technologies and technological progress. Working paper. INSEAD.

Prasad, E., Rogoff, K., Wei, S., \& Kose, M. (2009). Financial globalization: A reappraisal. IMF Staff Papers, 56, 8-62.
Quinn, D. (1997). The correlates of changes in international financial regulation. American Political Science Review, 91(3), 531-551.

Quinn, D., \& Inclan, C. (1997). The origins of financial openness: A study of current and capital account liberalization. American Journal of Political Science, 41(3), 771-813.

Quinn, D., \& Toyoda, A. M. (2008). Does capital account liberalization lead to economic growth? An empirical investigation. Review of Financial Studies, 21(3), 1403-1449.

Rajan, R. G., \& Zingales, L. (1998). Financial dependence and growth. American Economic Review, 88(3), 559-586.

Rajan, R. G., \& Zingales, L. (2003). The great reversals: The politics of financial development in the 20th century. Journal of Financial Economics, 69(1), 5-50.

Ranciere, R., Tornell, A., \& Westermann, F. (2008). Systemic crises and growth. The Quarterly Journal of Economics, 123(1), $359-406$.

Rodrik, D. (1998). Who needs capital account convertibility?. Princeton Essays in International Finance, 207, 1-10.

Solow, R. (1956). A contribution to the theory of economic growth. The Quarterly Journal of Economics, 70(1), 65-94.

Stiglitz, J. (2000). Capital market liberalization, economic growth, and instability. World Development, 28(6), 1075-1086.

Stiglitz, J. (2010). Risk and global economic architecture: Why full financial integration may be undesirable? NBER working paper.

Wacziarg, R., \& Welch, K. (2008). Trade liberalization and growth: New evidence. World Bank Economic Review, 22(2), 187-231.

Wade, R. (2004). Is globalization reducing poverty and inequality?. World Development, 32(4), 567-589.

Wurgler, J. (2000). Financial markets and the allocation of capital. Journal of Financial Economics, 58(1-2), 187-214.

\section{APPENDIX A}

See Tables A.1 and A.2.

Table A.1. Description of the variables

\begin{tabular}{ll}
\hline Variable & Description \\
\hline $\begin{array}{l}\text { Gross domestic product (GDP) and } \\
\text { its sub-components }\end{array}$ & $\begin{array}{l}\text { Real per capita gross domestic product. Available for all countries from 1980 to 2006. Source: World } \\
\text { Capital stock and total factor }\end{array}$ \\
Bank Development Indicators \\
We build per capita physical capital stocks over the 1980-2006 period using the method in King and \\
Levine (1994). We derive an initial estimate of the capital stock, assuming each country is at its steady- \\
state capital-output ratio at that time. Then, we use the aggregate real investment series and the perpetual \\
inventory method with a depreciation rate of 7\% to compute the capital stock in later years. TFP is \\
calculated as the difference between the GDP growth rate and 0.3 times the capital stock growth rate, \\
assuming a capital share of 0.3
\end{tabular}

Measures of financial openness Quinn capital account liberalization indicator

Official equity market liberalization indicator
Quinn's capital account openness measure is also created from the text of the annual volume published by the International Monetary Fund (IMF), Exchange Arrangements and Exchange Restrictions. Rather than the indicator constructed by the IMF that takes a 1 if any restriction is in place, Quinn's openness measure is scored $0-4$, in half integer units, with 4 representing a fully open economy. The measure hence facilitates a more nuanced view of capital account openness, and is available for 48 countries in our study. We transform the measure into a $0-1$ scale

Corresponding to a date of formal regulatory change after which foreign investors officially have the opportunity to invest in domestic equity securities. Official Liberalization dates are based on Bekaert and Harvey's (2005). A Chronology of Important Financial, Economic and Political Events in Emerging Markets, http://www.duke.edu/ charvey/chronology.htm. This chronology is based on over 50 different source materials. A condensed version of the chronology, along with the selection of dates for a number of countries appears in Bekaert and Harvey (2000). We have extended their official liberalization dates to include Japan, New Zealand, and Spain. For the liberalizing countries, the associated official liberalization indicator takes a value of one when the equity market is officially liberalized and thereafter, and zero otherwise. For the remaining countries, fully segmented countries are assumed to have an indicator value of zero, and fully liberalized countries are assumed to have an indicator value of one (continued on next page) 
Table A.1.-Continued

\begin{tabular}{|c|c|}
\hline Variable & Description \\
\hline $\begin{array}{l}\text { Intensity equity market liberalization } \\
\text { indicator }\end{array}$ & $\begin{array}{l}\text { Following Bekaert (1995) and Edison and Warnock (2003), the intensity measure is based on the ratio of the } \\
\text { market capitalization of the constituent firms comprising the IFC Investable index to those that comprise } \\
\text { the IFC global index for each country. The IFC Global index, subject to some exclusion restrictions, is } \\
\text { designed to represent the overall market portfolio for each country, whereas the IFC Investable index is } \\
\text { designed to represent a portfolio of domestic equities that are available to foreign investors. A ratio of one } \\
\text { means that all of the stocks are available to foreign investors. Fully segmented countries have an intensity } \\
\text { measure of zero, and fully liberalized countries have an intensity measure of one }\end{array}$ \\
\hline
\end{tabular}

Macroeconomic and demographic measures Initial GDP

Secondary school enrollment

Log life expectancy

Trade/GDP

Private credit/GDP

Illiquidity

Equity market turnover

\section{MCAP/GDP}

Price inefficiency

Investment profile

Quality of institutions

Law and order

Macro-economic environment
Logarithm of real per capita gross domestic product in 1980, 1985, 1990, 1995, or 2000 for the subsequent 5 years. Available for all countries. Source: World Bank Development Indicators

Secondary school enrollment ratio is the ratio of total enrollment, regardless of age, to the population of the age group that officially corresponds to the secondary level of education. Accordingly, the reported value can exceed (or average) more than $100 \%$. Available for all countries. Source: World Bank Development Indicators

Life expectancy at birth indicates the number of years a newborn infant would live if prevailing patterns of mortality at the time of its birth were to stay the same throughout its life. Available for all countries. Source: World Bank Development Indicators

The trade dependency ratio is the sum of exports and imports of goods and services measured as a share of gross domestic product. Available for all countries. Source: World Bank Development Indicators

Private credit divided by gross domestic product. Credit to private sector refers to financial resources provided to the private sector, such as through loans, purchases of non-equity securities, and trade credits and other accounts receivable that establish a claim for repayment. Available for all countries. Source: World Bank Development Indicators

Following Lesmond, Ogden, and Trzcinka (1999), Lesmond (2005), and Bekaert et al. (2007), we construct the illiquidity measure as the proportion of zero daily returns observed over the relevant year for each equity market. We obtain daily returns data in local currency at the firm level from the Datastream research files. For each country, we observe daily returns (using closing prices) for a large collection of firms. The total number of firms available from the Datastream research files accounts for about $90 \%$, on average, of the number of domestically listed firms reported by the World Bank's World Development Indicators. For each country, we calculate the capitalization-weighted proportion of zero daily returns across all firms, and average this proportion over the year. Available for 46 countries

The ratio of equity market value traded to the market capitalization. The data are available for 51 countries. Source: Standard and Poor's/International Finance Corporation's Emerging Stock Markets Factbook

The ratio of equity market capitalization to gross domestic product. The data are available for 51 countries. Source: Standard and Poor's/International Finance Corporation's Emerging Stock Markets Factbook

Equity market synchronicity as developed in Morck et al. (2000). The measure is an annual valueweighted local market model $R^{2}$ obtained from each firm's returns regressed on the local market portfolio return for that year. Available for 47 countries

ICRG political risk sub-component. This is a measure of the government's attitude to inward investment. The investment profile is determined by PRS's assessment of three sub-components: (i) risk of expropriation or contract viability; (ii) payment delays; and (iii) repatriation of profits. Each subcomponent is scored on a scale from zero (very high risk) to four (very low risk). Source: Various issues of the International Country Risk Guide

The sum of the International Country Risk Guide (ICRG) political risk sub-components: corruption, law and order, and bureaucratic quality. Source: Various issues of the International Country Risk Guide

ICRG political risk sub-component. ICRG assesses law and order separately, with each sub-component comprising zero to three points. The law sub-component is an assessment of the strength and impartiality of the legal system, while the order sub-component is an assessment of popular observance of the law. Thus, a country can enjoy a high rating (3.0) in terms of its judicial system, but a low rating (1.0) if the law is ignored for a political aim. Source: Various issues of the International Country Risk Guide

The value of the International Country Risk Guide (ICRG) economic risk indicator (which ranges between 0 and 50). The risk rating is a combination of five sub-components: GDP levels and growth, respectively, inflation, balanced budgets, and the current account. The minimum number of points for each component is zero, while the maximum number of points depends on the fixed weight that component is given in the overall economics risk assessment. Source: Various issues of the International Country Risk Guide 
Table A.1.-Continued

\begin{tabular}{|c|c|}
\hline Variable & Description \\
\hline Growth opportunities & $\begin{array}{l}\text { Growth opportunities are global measures of country-specific growth opportunities. Growth } \\
\text { opportunities are measured as the log of the inner product of the vector of global industry PE ratios and } \\
\text { the vector of country-specific industry weights. Country-specific industry weights are determined by } \\
\text { relative equity market capitalization. Then, a } 60 \text {-month moving average is removed. Available for } 51 \\
\text { countries. Source: Bekaert et al. (2007) }\end{array}$ \\
\hline Antidirector rights & $\begin{array}{l}\text { An index aggregating different shareholder rights. The index is formed by adding } 1 \text { when: (1) the country } \\
\text { allows shareholders to mail their proxy vote to the firm; (2) shareholders are not required to deposit their } \\
\text { shares prior to the General Shareholders' Meeting; (3) cumulative voting or proportional representation } \\
\text { of minorities in the board of directors is allowed; (4) an oppressed minorities mechanism is in place; (5) } \\
\text { the minimum percentage of share capital that entitles a shareholder to call for an Extraordinary } \\
\text { Shareholders' Meeting is less than or equal to } 10 \% \text { (the sample median); or (6) shareholders have } \\
\text { preemptive rights that can only be waved by a shareholders' vote. The index ranges from } 0 \text { to } 6 \text {. This } \\
\text { variable is purely cross-sectional, and available for } 47 \text { countries. Source: La Porta, Lopez-de-Silanes, } \\
\text { Shleifer, and Vishny (1998) }\end{array}$ \\
\hline Political risk rating & $\begin{array}{l}\text { The political risk rating indicator which ranges between } 0 \text { (high risk) and } 100 \text { (low risk). The risk rating is } \\
\text { a combination of } 12 \text { sub-components. Source: Various issues of the International Country Risk Guide }\end{array}$ \\
\hline
\end{tabular}

All data are employed at the annual frequency.

Table A.2. Summary statistics

\begin{tabular}{|c|c|c|c|c|c|c|c|}
\hline & $\begin{array}{l}\text { GDP } \\
\text { growth }\end{array}$ & $\begin{array}{l}\text { Capital } \\
\text { stock growth }\end{array}$ & $\begin{array}{l}\text { Productivity } \\
\text { growth }\end{array}$ & $\begin{array}{l}\text { Productivity } \\
\text { growth (alt.) }\end{array}$ & $\log ($ initial GDP) & $\begin{array}{l}\text { Secondary school } \\
\text { enrollment }\end{array}$ & $\begin{array}{c}\log (\text { life } \\
\text { expectancy })\end{array}$ \\
\hline Mean & 0.013 & 0.015 & 0.009 & 0.009 & 7.711 & 0.606 & 4.149 \\
\hline Median & 0.018 & 0.013 & 0.014 & 0.014 & 7.548 & 0.570 & 4.220 \\
\hline Standard deviation & 0.046 & 0.029 & 0.043 & 0.039 & 1.616 & 0.342 & 0.196 \\
\hline \multirow[t]{2}{*}{ No. of countries } & 96 & 96 & 96 & 77 & 96 & 96 & 96 \\
\hline & Trade/GDP & $\begin{array}{c}\text { Private } \\
\text { credit/GDP }\end{array}$ & $\begin{array}{l}\text { Capital account } \\
\text { openness }\end{array}$ & $\begin{array}{c}\text { Official equity market } \\
\text { liberalization }\end{array}$ & $\begin{array}{c}\log (\text { market illiquidity }) \\
\text { [zero returns] }\end{array}$ & Turnover/GDP & MCAP/GDP \\
\hline Mean & 0.725 & 0.466 & 0.625 & 0.429 & -1.428 & 0.395 & 0.412 \\
\hline Median & 0.614 & 0.312 & 0.625 & 0.000 & -1.341 & 0.220 & 0.240 \\
\hline Standard deviation & 0.480 & 0.410 & 0.272 & 0.495 & 0.715 & 0.513 & 0.485 \\
\hline \multirow[t]{2}{*}{ No. of countries } & 96 & 96 & 78 & 96 & 47 & 73 & 73 \\
\hline & $\begin{array}{c}\text { Price } \\
\text { inefficiency }\end{array}$ & $\begin{array}{l}\text { Investment } \\
\text { profile }\end{array}$ & $\begin{array}{l}\text { Quality of } \\
\text { institutions }\end{array}$ & $\begin{array}{l}\text { Law and } \\
\text { order }\end{array}$ & $\begin{array}{l}\text { Macro-economic } \\
\text { conditions }\end{array}$ & $\begin{array}{l}\log (\text { country } \\
\text { credit rating) }\end{array}$ & \\
\hline Mean & 0.227 & 0.586 & 0.579 & 0.615 & 0.632 & 3.671 & \\
\hline Median & 0.213 & 0.583 & 0.563 & 0.667 & 0.649 & 3.742 & \\
\hline Standard deviation & 0.126 & 0.200 & 0.242 & 0.269 & 0.145 & 0.647 & \\
\hline No. of countries & 46 & 86 & 86 & 86 & 86 & 73 & \\
\hline
\end{tabular}

All data are employed at the annual frequency. 